This article has been scanned by iThenticat No plagiarism detected

Volume 3, Issue 6, December 2021

p. $608-627$

\title{
THE IMPACT OF MOTIVATION ON ORGANIZATIONAL BEHAVIOR
}

http://dx.doi.org/10.47832/2757-5403.6-3.46

\begin{abstract}
:
The study aimed to identify the impact of motivation on organizational behaviour. The descriptive analytical approach was used, through a questionnaire that included four axes. The study sample included (54) teachers working in two secondary schools based in East Jerusalem. The data was processed using the statistical analysis program (SPSS), and the Pearson test was used to determine the extent of the association, in addition to the ANOVA test to examine the research hypotheses. The results indicated that the most important manifestations of incentives and their impact on organizational behaviour from the teachers' point of view are they receive transportation allowances to and from school, secondly, the school also engages them in development courses as needed, and thirdly, it involves teachers in making special decisions. It also showed that the most important manifestations of organizational behaviour from the teachers' point of view is represented in that the school occupies advanced results at the academic level, and that the school is progressing in its performance during the current year, and their sense of respect and appreciation from all employees in their institution. As for the hypotheses, the study showed that there were no statistically significant differences in the degree of motivation and its impact on organizational behaviour due to the variables of gender and academic qualification, and showed that there are statistically significant differences in the degree of

motivation and its impact on the organizational behaviour due to the variable of age and in favour of teachers whose age is (less than 30), and there are statistically significant differences due to the variable years of experience, and in favour of teachers who have years of experience (5 to less than 10).
\end{abstract}

\footnotetext{
${ }^{1}$ Researcher , Arab American University, Palestine, Oraibtwaari@gmail.com, https://orcid.org/0000-0001$\underline{7922-3108}$
}

Copyright (C) Published by IJHER Journal, www.ijherjournal.com Rimar Academy, Fatih, Istanbul, 34093 Turkey

All rights reserved 


\section{THE IMPACT OF MOTIVATION ON ORGANIZATIONAL BEHAVIOR}

عنصريين أساسيين هما: المقدرة على العمل ودرجة الرضا عنه وبالتالي الرغبة فيه، وهذه الرغبة تمثلها الحوافز التي

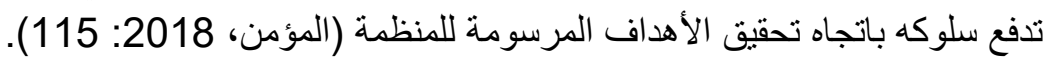

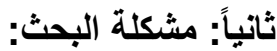

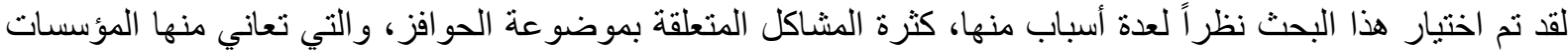

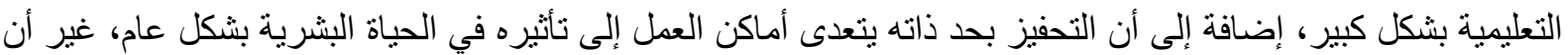

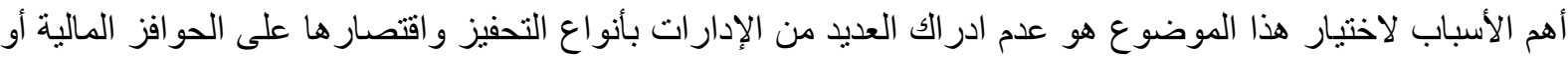

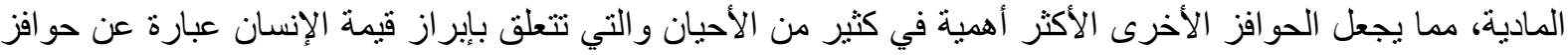

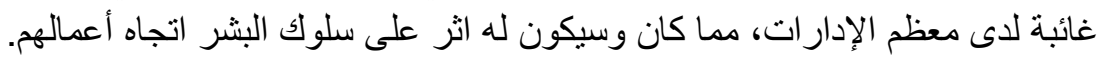

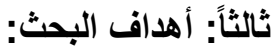

يهدف البحث إلى الكثف عن تأثثر الحوافز المادية والمعنوية بكافة أنثكالها على السلوك التنظيمي للمعلمين من وجهة

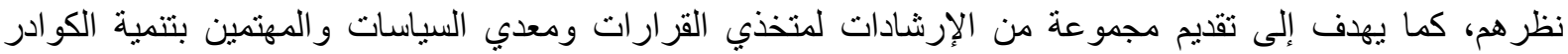
البشرية في القطاع التربوي، و الىى توفير مجموعة من التوصيات حول أهم عناصر التحفيز ذات التهات الأهمية و التي تعاني من عدم اهتمام من قبل المسؤولين.

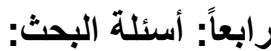

سؤال البحث المركزي: ما أثر التحفيز على السلوك التنظيمي في مدارس القدس الثرقية الثنانوية؟

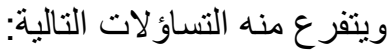

• ما درجة التحفيز وأثره على السلوك التنظيمي للمعلمين و المعلمات في مدرسة الفرير الثانوية ألمختلطة و المدرسة الر اشدية للبنين من وجهة نظر المعلمين؟ عالئ • ما أهم مظاهر الحوافز وتأثيرها على والثي السلوك التنظيمي للمعلمين و المعلمات في مدرسة الفرير الثانوية ألمختلطة

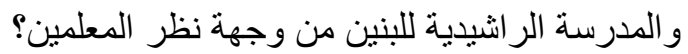

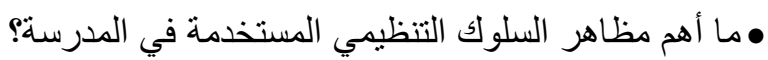

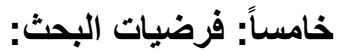

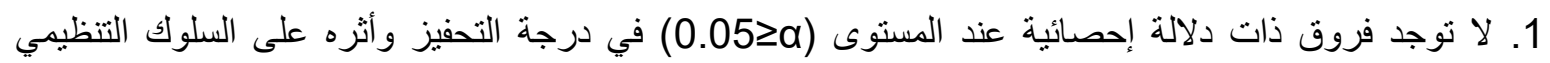
تعزى لمتغير الجنس.

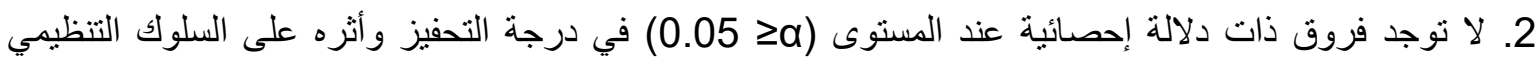
تعزى لمتغير العمر.

3. لا نوجد فروق ذات دلالة إحصائية عند المستوى (a) تعزى لمتغير المؤهل العلمي.

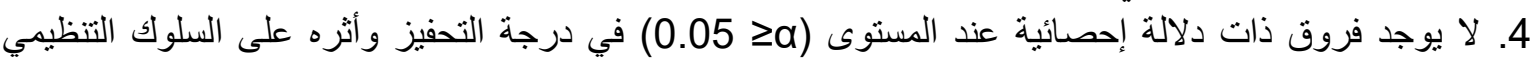
تعزى لمتغير سنوات الخبرة. سادساً: مجتمع وعينة البحث: تتكون عينة الدراسة من (54) معلم ومعلمة موزعين على مدرستين في شرقي القدس وهم مدرسة الفرير الثانوية

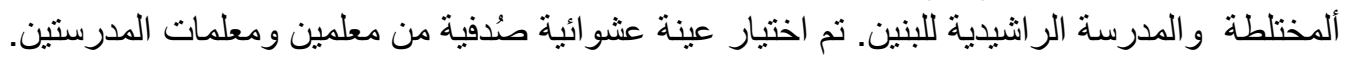



تم استخدام استبيان كأداة رئيسية لإجراء البحث، وقد بني خصيصًا لغرض البحث، وذللك بناءًا على الإطار النظري،

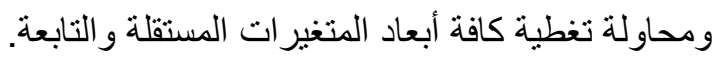

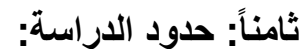

ـ الحد المكاني: المدرسة الر اشيدية للبنين ومدرسة الفرير الثانوية المختلطة في شرقي القدس.

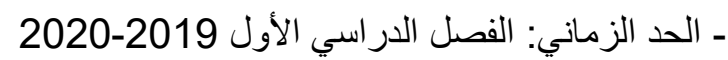
ـ الحد البشري: المعلمون والمعلمات في مدرسة الفرير الثانوية ألمختلطة والمدرسة الر اشيدية الثانوية للبنين.

الإطار النظري

التحفيز

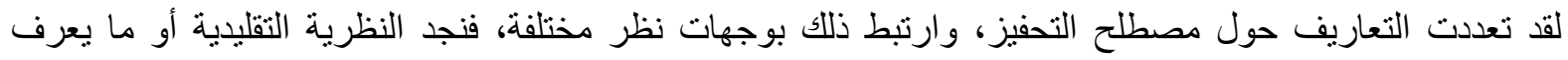

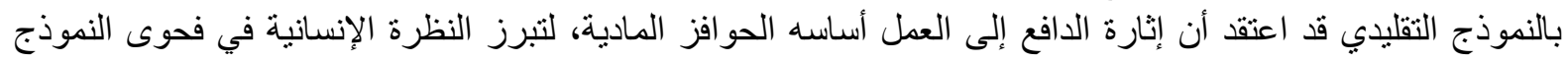

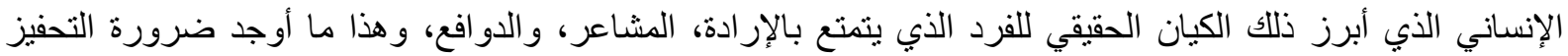

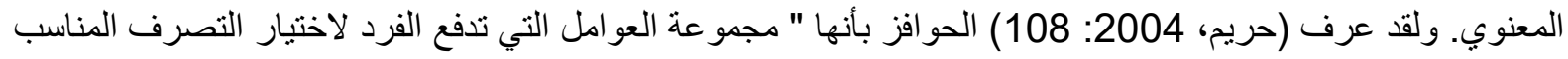

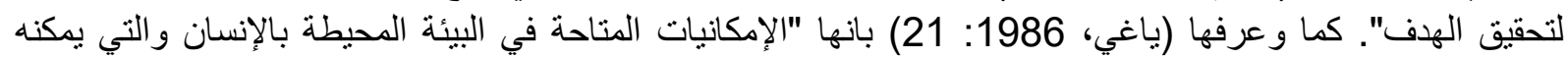

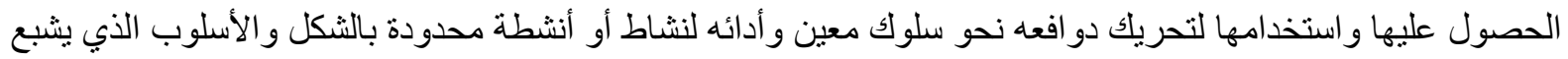

حاجاته وتوقعاته وتحقيق أهدافه".

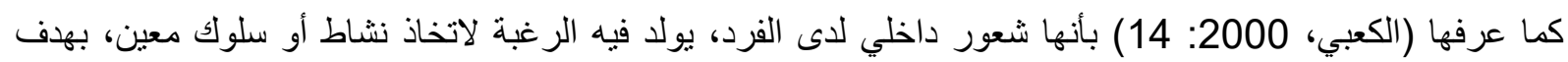

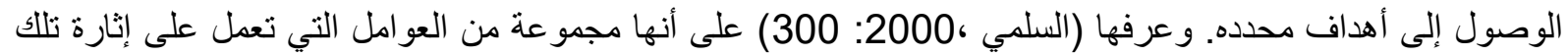

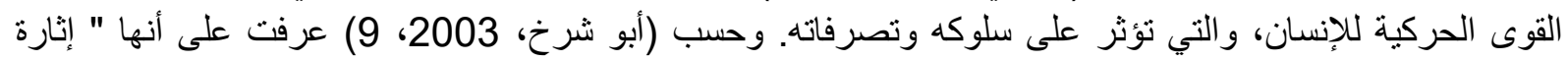

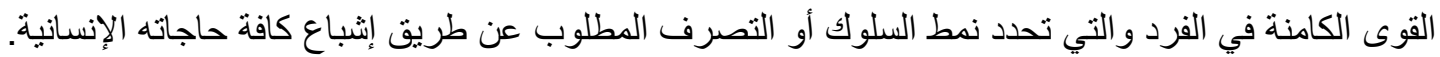

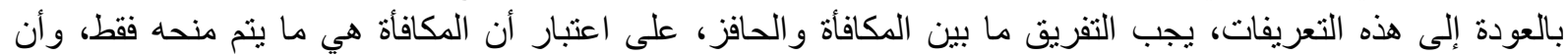

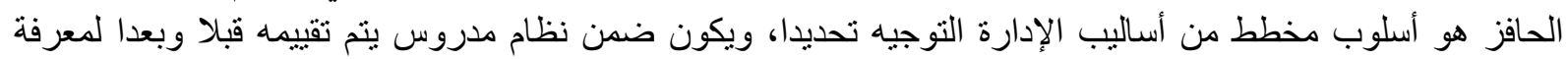

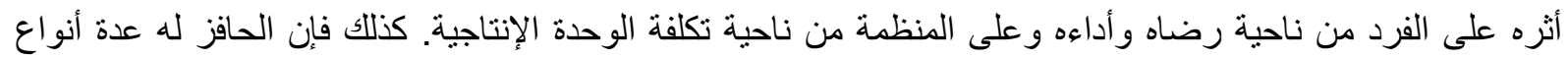

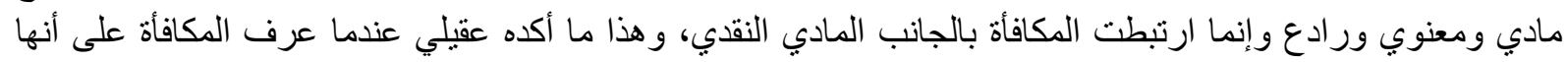

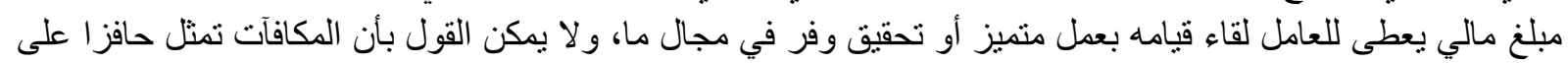

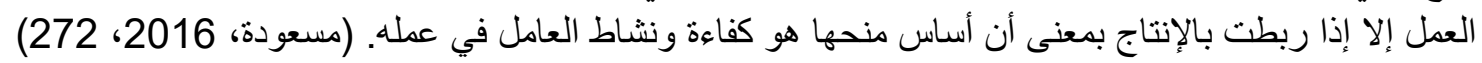

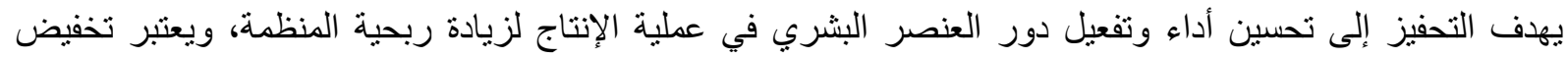

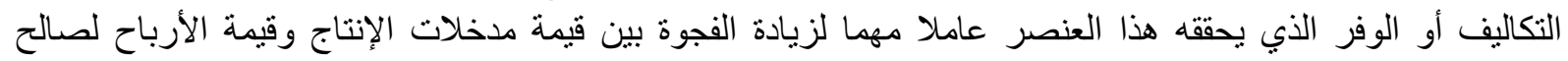

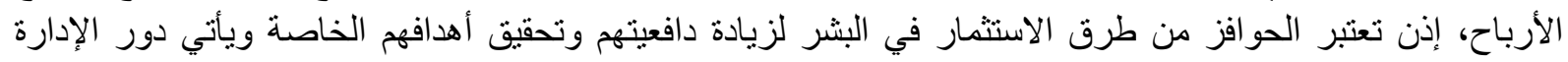

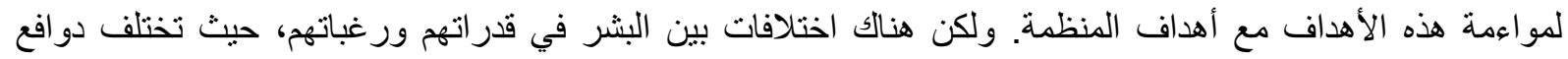

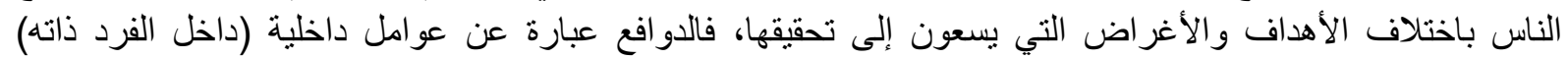

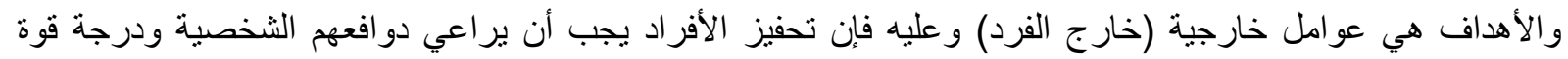

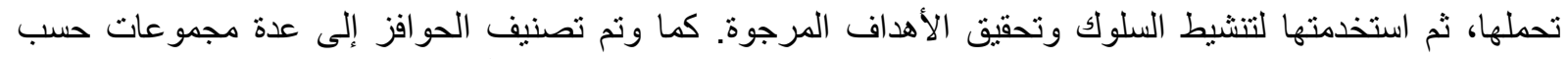

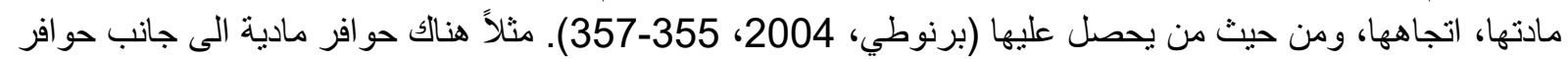

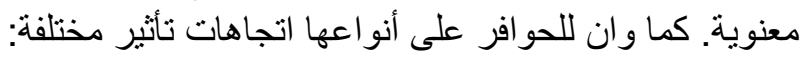

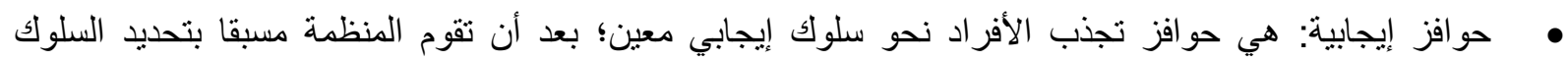

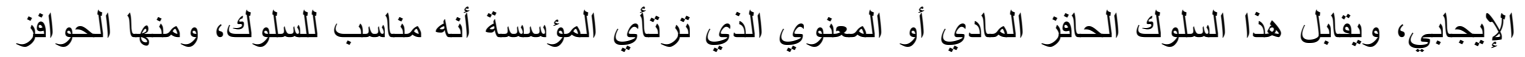




\section{THE IMPACT OF MOTIVATION ON ORGANIZATIONAL BEHAVIOR}

المالية، الاستقرار الوظيفي، الثناء والمديح والتقدير، المنافسة، المعرفة والإبلاغ بالنتائج (الأثر الناتج عن الأداء)،

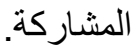

حوافز سلبية/ منفرة: تستخدم المنظمة هذه الحو افز لتدفع العاملين إلى تجنب سلوك غير مرغوب، ويمكن أن تكون

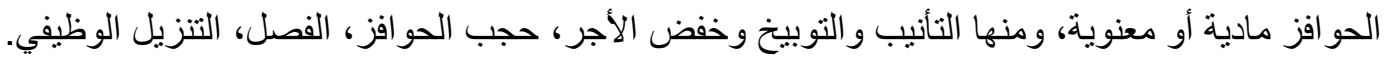
• الحو افز من حيث من يحصل عليها:

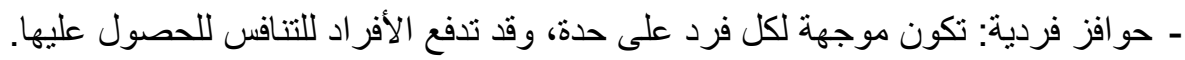
ـ حو افز جماعية: حو افز تقدم للجماعات حيث تقوم الجماعات بالمنافسة فيما بينها للحصول على الحئ الحو افز في المقابل

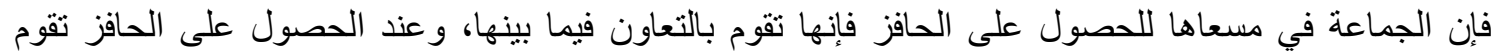
الجماعة بتقسيمه على أفر ادها. - وقسم الحو افز حسب مصدر ها إلى قسمين: - حوافز داخلية: تكمن أهميتها في طبيعة العمل الذي يؤديه العامل من حيث تعقد المهام، درجة المسؤولية الممنوحة للعامل، ومدى تو افق ذللك مع قدر اته وطموحاته. ـ حوافز خارجية: تمثل هذه الحوافز الظروف المحيطة بالعمل وليس العمل نفسه، ومن أمثلتها؛ الأجر، المكافآت، ظروف العمل المادية. (مسعودة، 2016، 274-274). كما وتم تقسيمها إلى حوافر مبانشرة (المادية منها) وحو افز غير مباشرة (مثلاً التو افق بين زملاء العمل، الأمن الاجتماعي، المشاركة، حرية التعبية التعبير). حتى يكون التحفيز فعال ويحقق أهدافه فيجب أن يكون منوافق مع رغبات الموظف من جهة، ومربوط بالإنجاز من جهة أخرى، فإذا لم تتوفر هذه الثروط سوف تتحول الحوافز من وسيلة لزيادة الإنتاجية إلى وسيلة إحباط نفسية للعاملين،

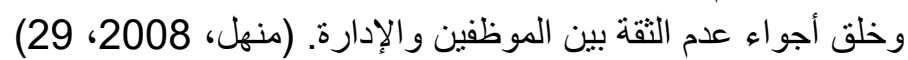

وأيضا من شروط تحقيق التحفيز الفعال:

- - أن تكون الحوافز متناسبة مع الجهد المبذول، فلبس من العدل منح مكافأة كبيرة مقابل عمل عادي، أو *دفع مكافأة ضئيلة تجاه عمل كبير أو إبداع متميز.

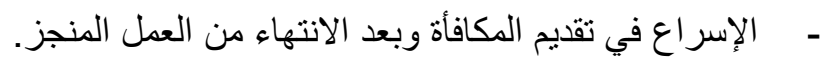
- لتتوع في تقديم المكافأة حنى لا يمل الموظف من الحصول على نفس الحافز وحتى لا يفقده قيمته، *فمن

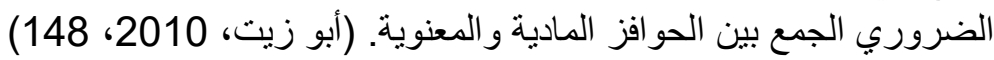

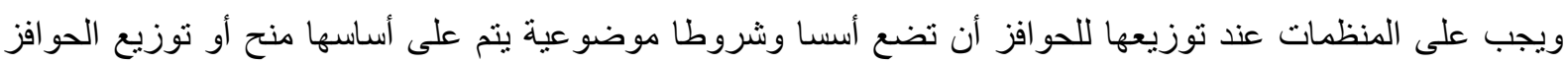

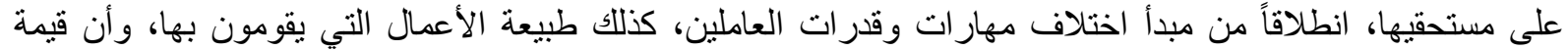

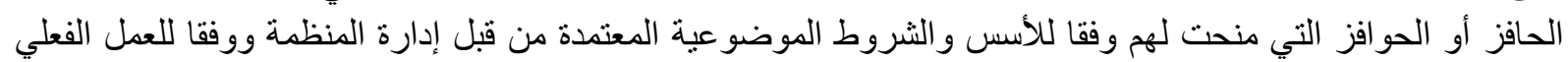

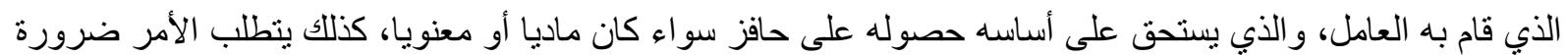

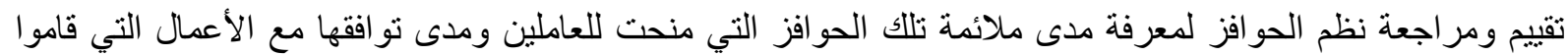
بها، وذللك لمعرفة جو انبها الإيجابية لتعزيزها والجوانب السلبية لعلاجها، و اقتراح الطرق العلمبة التي تسهم في بناء نظام

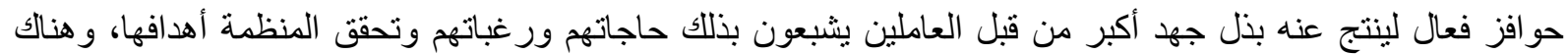

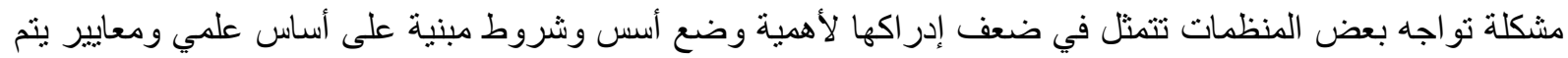

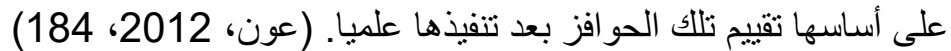

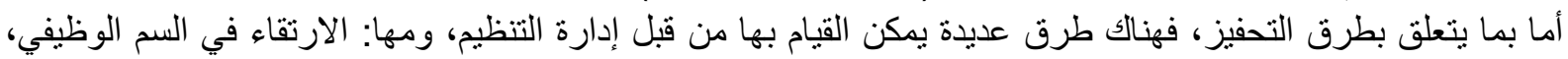

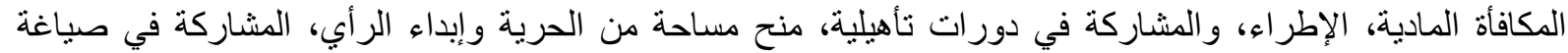

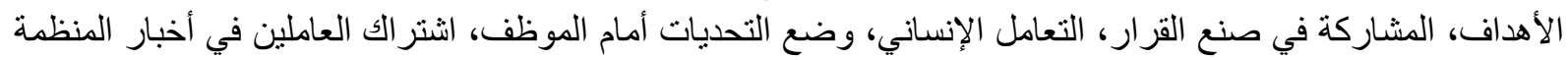

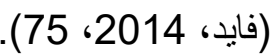


هو سلوك الأفر اد داخل المنظمات. ويقصد بالسلوك: الاستجابات التي تصدر عن الفرد نتيجة لاحتكاكه بغيره من الأفراد

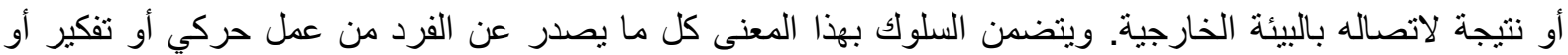

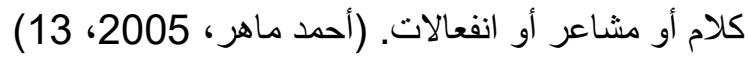
ويقصد بالمنظمات: تللك المؤسسات التي ينتمي الفرد إليها، وتهدف التهات إلى إلى تقديم نفع وقيمة جديدة، كالمصانع والبنوك

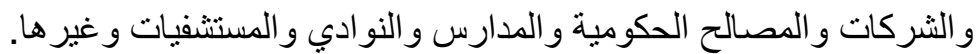

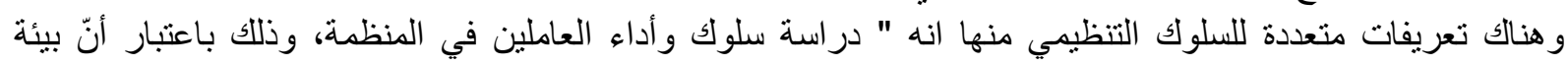

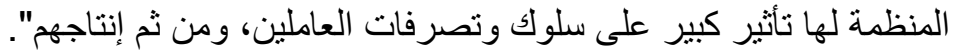

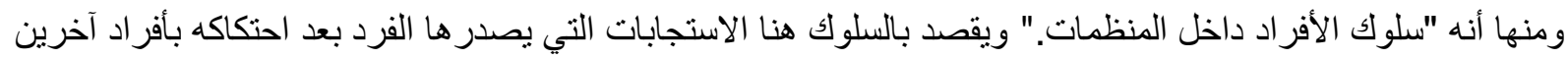

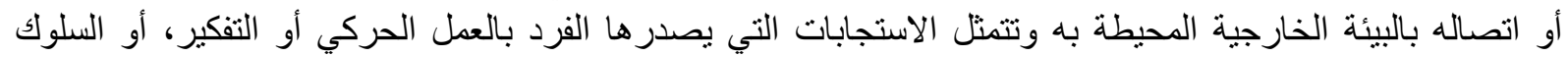

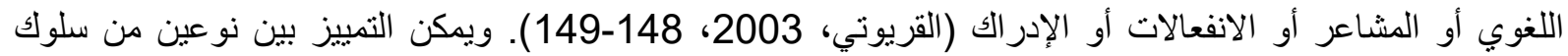

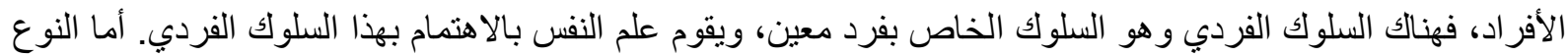

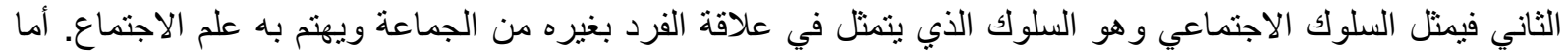

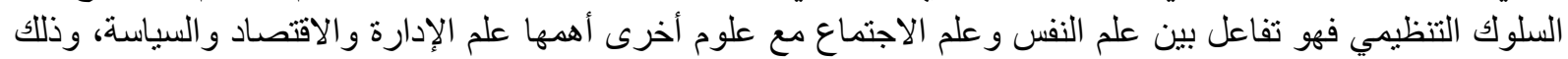

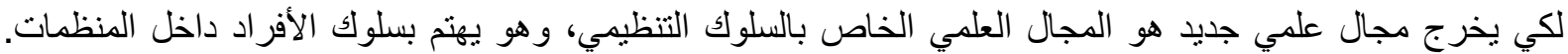

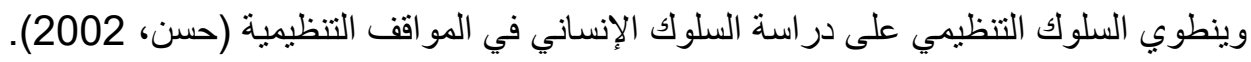

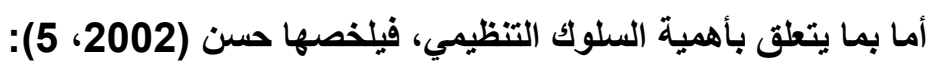
1. تعد الموارد البشرية مورد هام للمنظمة لذلك استلزم ضرورة الاهتمام بدراسة وفهم سلوك الأفر اد لما لها تأثثير

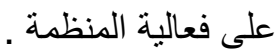

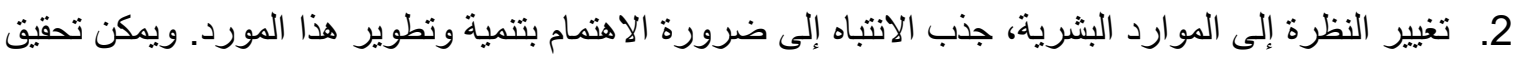

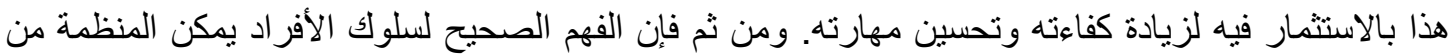

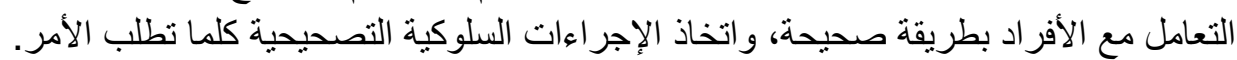

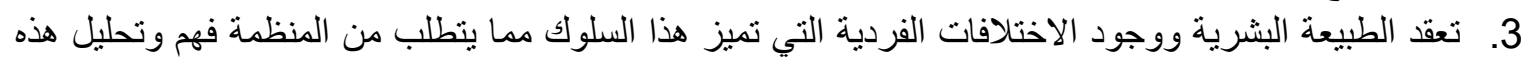

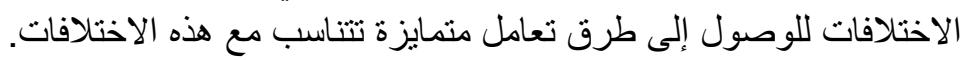

كما ويهدف السلوك التنظيمي بصفة عامة إلى بتنمية مهارات الأفراد. فالمنظمات ذات الفعالية العالية، نتجع مديريها كي

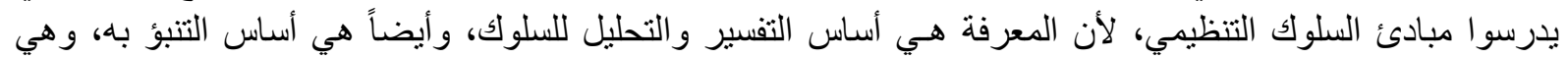

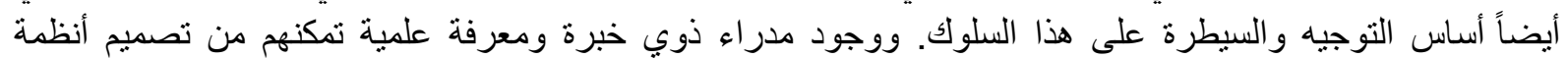
وقواعد وسياسات ذات تأثثير على سلوك العاملين، ذلك أنها تعتمد على معرفة علمية بكيفية التفسير والتنبؤ بسلوك

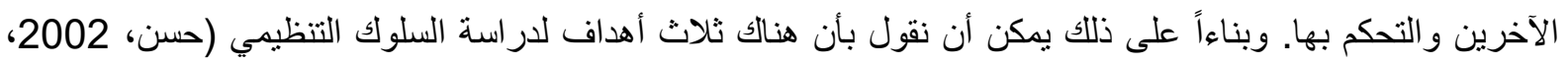

$$
\text { 1. 1 التعرف على مسببات السلوك. }
$$

2. التتبؤ بالسلوك في حالة التعرف على هذه المسبيات. 3. التوجيه و السيطرة و التحكم في السلوك من خلال التأثير في المسبيات.

نظريات السلوك التنظيمي

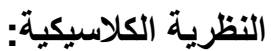

تنشير النظرية الكلاسيكية إلى النظرية القديمة في تفسير السلوك الإنساني. ولقد افترضت النظرية الكلاسيكية مع اختلاف نماذج بأن الأفر اد كسالى، و أنهم غير قادرين على تتظيم وتخطيط العمل، وكذلك غير عقلانيين، و انفعاليين، ولهذه الأسباب

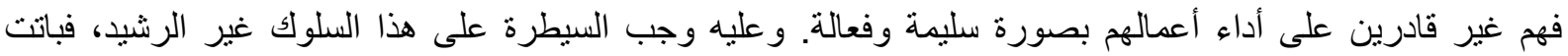

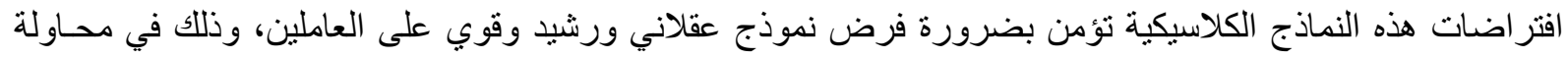




\section{THE IMPACT OF MOTIVATION ON ORGANIZATIONAL BEHAVIOR}

السيطرة والتحكم في السلوك داخل المنظمات، وسيعرض فيما يلي لكل من نموذج الإدارة العلمية، ونموذج العملية الإدارية، و النموذج البيروقر اطني.

نظرية العلاقات الإنسانية:

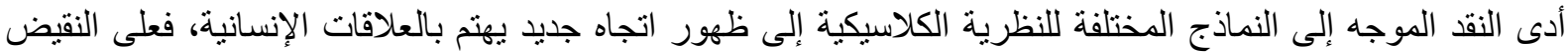

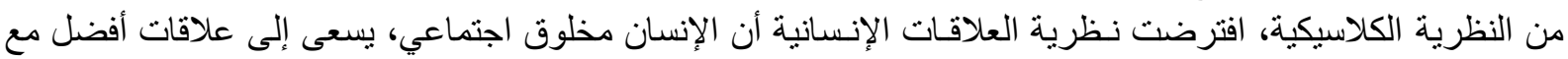

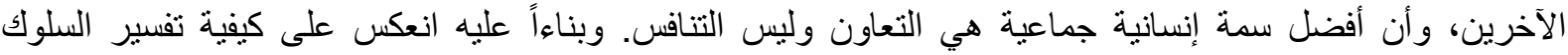
الإنسـاني و التنبؤ به و التحكم فيه في نظرية العلاقات الإنسانية ويمكن تلخيص أهم مبادئ النظرية الكلاسيكية الحديثة أو الو نظرية العلاقات الإنسانية في ما بلي:

1 1. يتأثر الناس في سلوكهم داخل العمل باحتياجاتهم الاجتماعية.

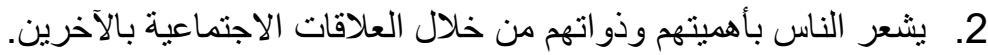

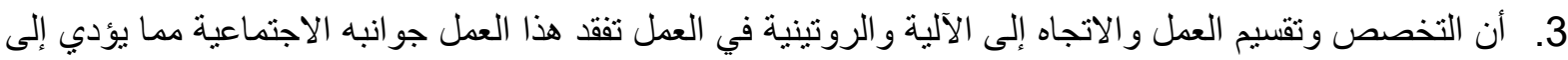
الملل و السأم.

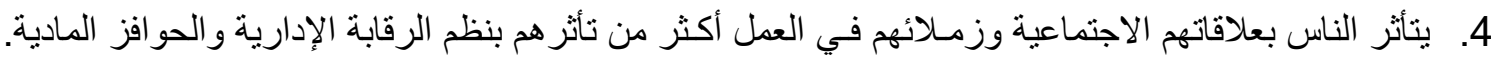

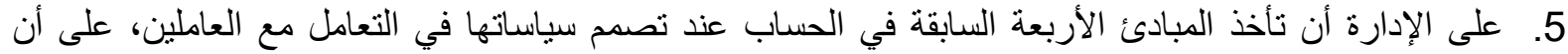

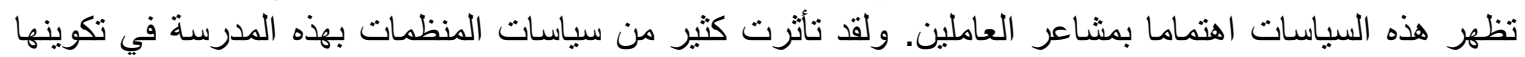

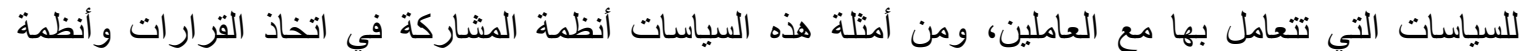

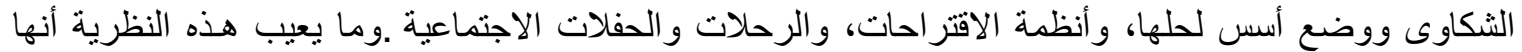

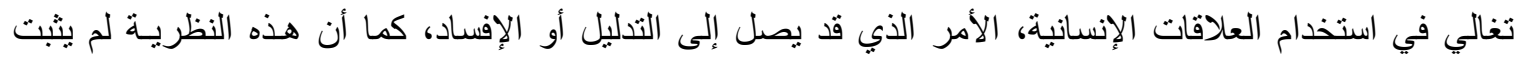
بالتجربة أن لها تأثثير واضـح وفعال على إنتاجية العاملين. (العضايله، 1996، 23-25)

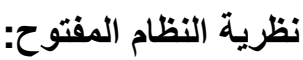

أدرك علماء التنظيم والإدارة أن المنظمات ليست ساكنة، بل متحركة، فهي تحصل على مواردها لتها من المجتمع، ومن خلال

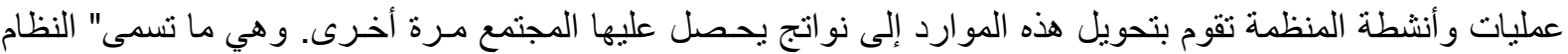
المفتوح."

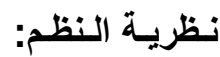

ويمكن تطبيق فكرة النظام المفتوح على أي شيء تقريباً. فيمكن مثلاً أن نقول أن العمال يؤدون عملهم من أجل الحصول

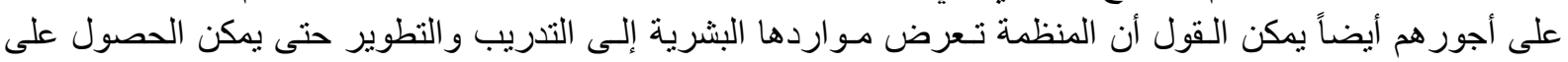

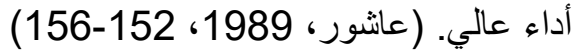

النظريـة الموقفية:

ويوضح أن هناك عناصر في الفرد مثل: إدر اكه، و عمره، وجنسه، وتعليمه ومهارته، وحاجاته، وشخصيته، و اتجاهاته

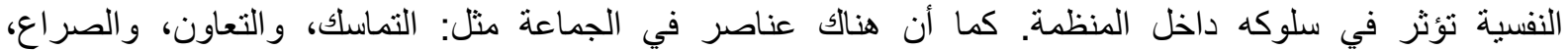

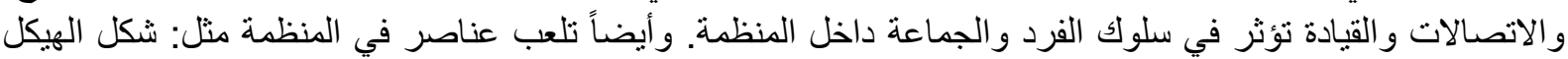

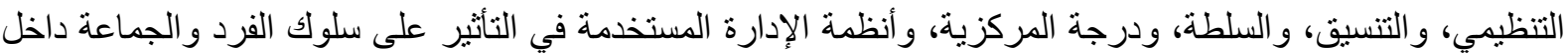

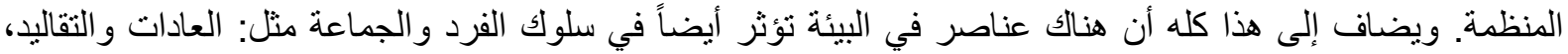

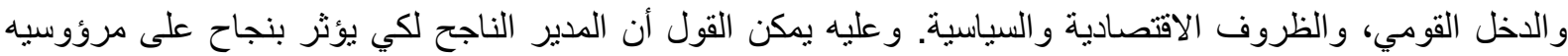
عليه أن يأخذ كافة عناصر الموقف الفرد، والجماعة، والمنظمة، والبيئة في الحسبان عند تدخله بالتأثير في سلوك التك

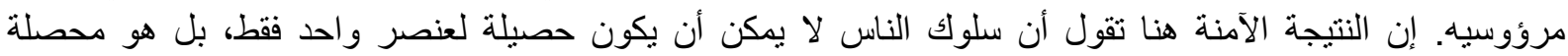

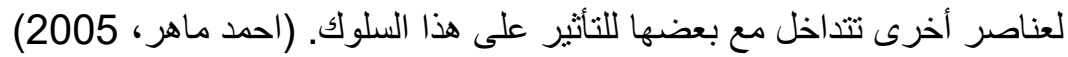

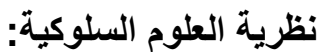

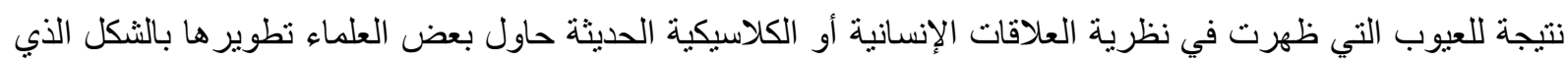
يسمح باستخدام كل الجوانب السلوكية للناس لإعطاء تفسيرات أكثر دقة للأداء الناجح في الأعمال. فبينما ركزت نظرية الإناء 
العلاقات الإنسانية على الاهتمام بمشاعر الناس لدرجة المبالغة والتدليل و الإفساد، فإن النظريات الحديثة تحاول أن تعطي

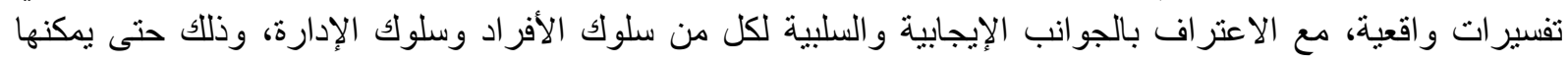

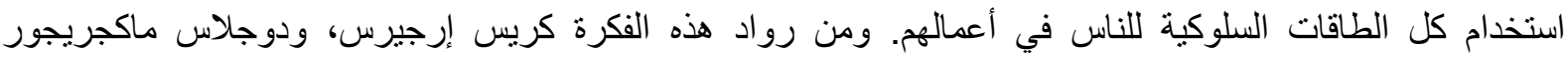
ورنسيس ليكرت، وابر اهام مازلو، وفريديريك هرزبرج، و العديد من علماء السلوك و ولماء الفاء الإدارة المعاصرين.

\section{دراسات سابقة}

دراسة (المؤمن: 2018) بعنوان " أثر التحفيز على الرضا الوظيفي "

وقد هدف الباحث إلى اختبار دور سياسات التحفيز المادي والمعنوي على رضا العاملين في شركة زين الكويتية، حيث

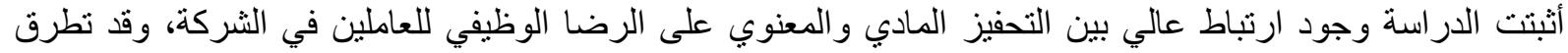

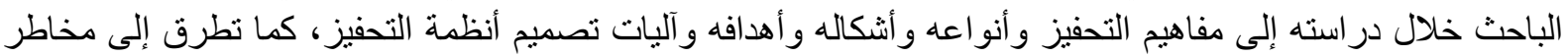

انعدامه. دراسة سلطان (2013) بعنوان " تأثير الحوافز على فعالية الأداء و الرضا الوظيفي في أمانة القصيم: دراسة مسحية

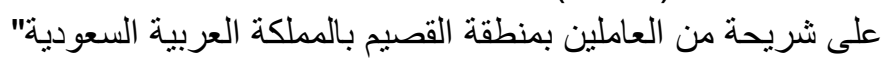

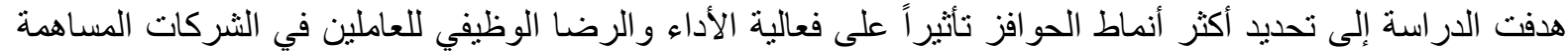

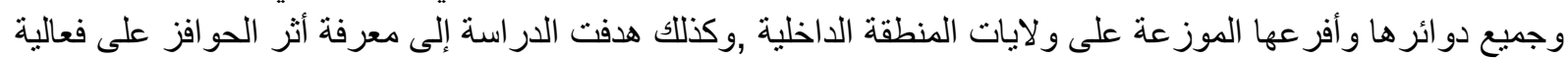
الأداء الوظيفي للعاملين ,وقد استخدم الباحث المنهج الوصفي التحليلي ,حيث تم اختيار العينة بالطريقة العشوائية الطبقية

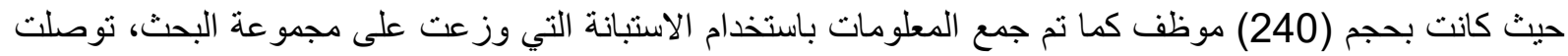

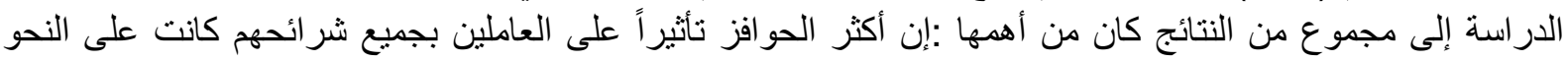

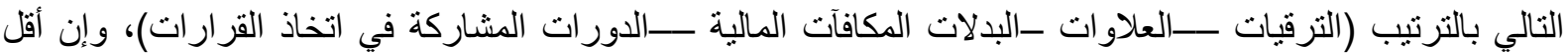

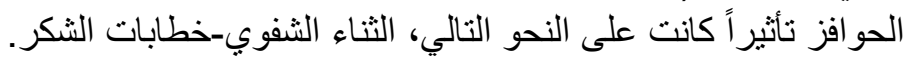

دراسة (العرفج: 2009)

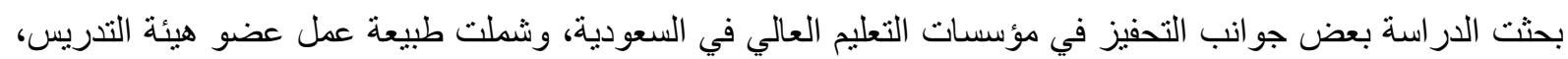

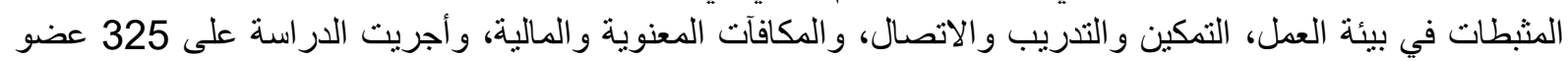

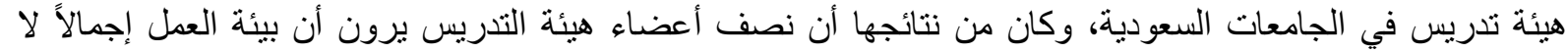

تدعم و لائهم للجامعة التي يعملون فيها، و انه يمكن تصميم العمل لكل عضو في هيئة التدريس ليكون أكثر و ولاء لـاء لعمله.

منهجية البحث

بحث كمي منهجي وصفي تحليلي اتبعت الباحثة المنهج الوصفي التحليلي، حيث قامت بوصف الظاهرة من خلال

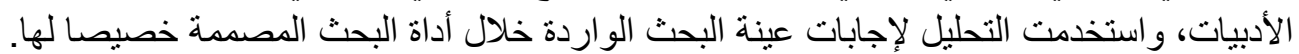

عينة البحث

شملت عينة البحث (54) معلم ومعلمة من المدرستين في شرقي القد تم اختيار هم بشكل عشوائي من مجتمع البحث.

معالجة البيانات

تمت المعالجة الإحصائية اللازمة للبيانات، باستخراج الأعداد، والنسب المئوية، والمتوسطات الحسابية، والانحرافات

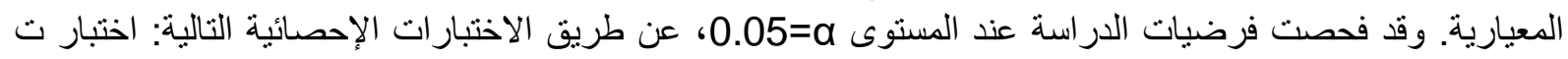

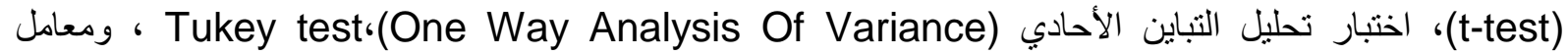

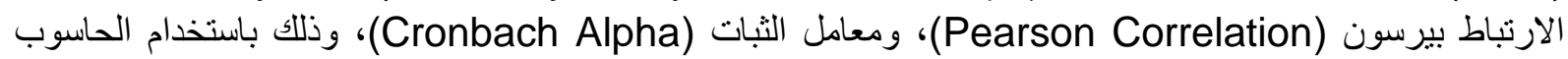
باستخدام برنامج الرزم الإحصائية للعلوم الاجتماعية (Spss). سلم المتوسط الحسابي 


\section{THE IMPACT OF MOTIVATION ON ORGANIZATIONAL BEHAVIOR}

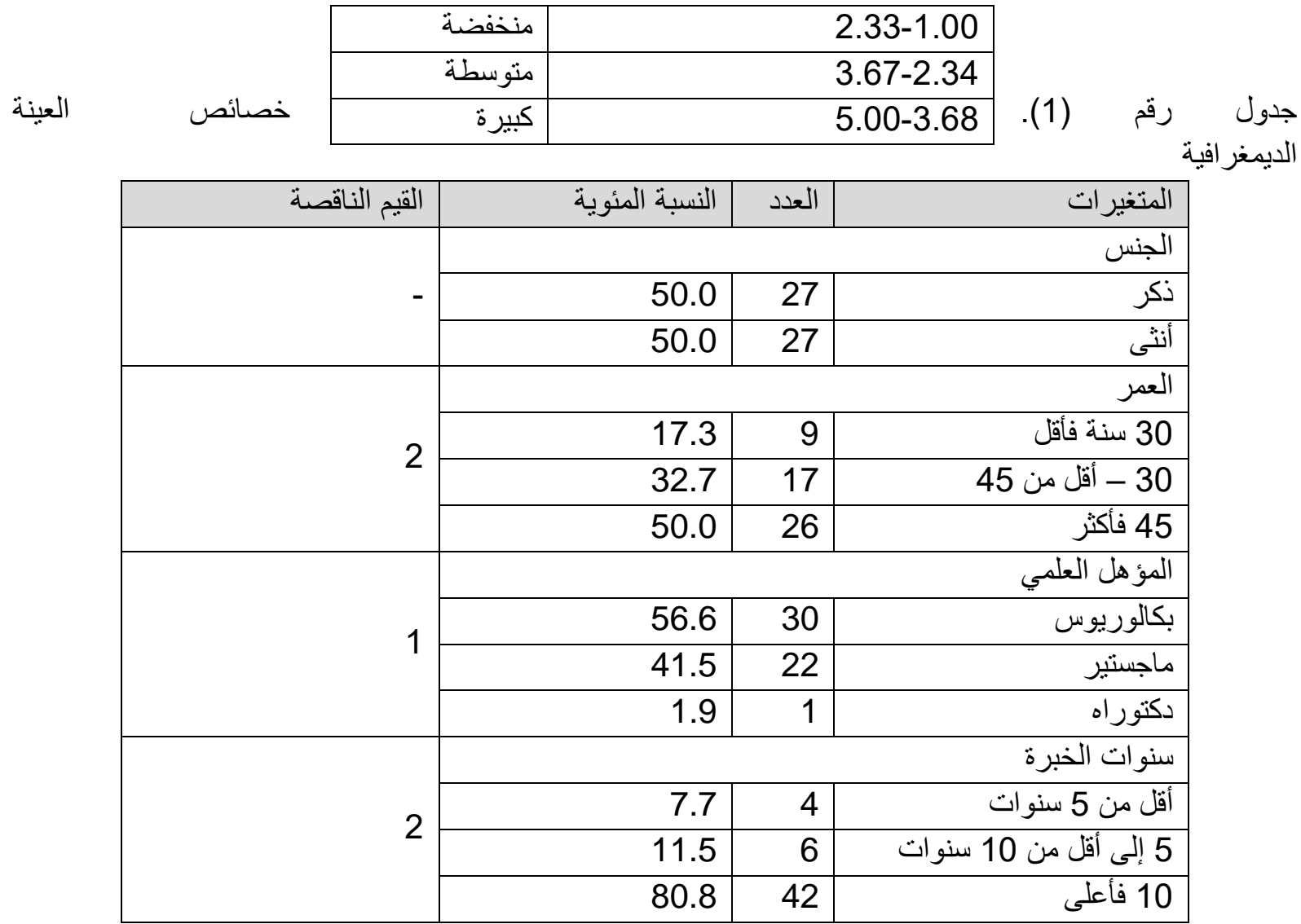

صدق مقياس الدراسـة

تم التحقق من صدق أداة الدر اسة بعرضها على أخصائيين نربويين الذين أبدوا بعض الملاحظات حولها، و عليه نم إخراج أداة الدر اسة بشكلها الحالي. جدول رقم (2): نتائج معامل الارتباط بيرسون (Person correlation) لمصفوفة ارتباط فقرات أداة الدراسة مع الدجة الكلية للأداة

\begin{tabular}{|c|c|c|c|c|c|}
\hline الدلالة الإحصائية & قيمة (ر) & الفقر ات & الدلالة الإحصـائية & قيمة (ر) & الفقرات \\
\hline 0.000 & .4510 & 15 & 0.000 & .6170 & 1 \\
\hline 0.001 & .4470 & 16 & 0.000 & .7510 & 2 \\
\hline 0.000 & 6040 & 17 & 0.000 & .4580 & 3 \\
\hline 0.000 & .6360 & 18 & .2730 & .1520 & 4 \\
\hline 0.000 & .5410 & 19 & 0.005 & .3750 & 5 \\
\hline 0.000 & .5060 & 20 & .3650 & .1260 & 6 \\
\hline 0.001 & .4560 & 21 & .8700 & .0230 & 7 \\
\hline 0.000 & .5410 & 22 & 0.000 & .5320 & 8 \\
\hline 0.000 & .5300 & 23 & 0.000 & .7270 & 9 \\
\hline .9310 & .0120 & 24 & 0.000 & .6980 & 10 \\
\hline 0.000 & .6840 & 25 & 0.000 & .6180 & 11 \\
\hline .0920 & .2320 & 26 & 0.000 & .7150 & 12 \\
\hline 0.000 & .7450 & 27 & 0.000 & .5680 & 13 \\
\hline & & & 0.000 & .5480 & 14 \\
\hline
\end{tabular}


يتضح من الجدول السابق أن أغلبية قيم ارتباط الفقرات مع الدرجة الكلية للمقياس دالة إحصائيا، مما يشير إلى الاتساق

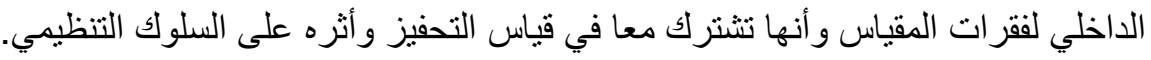

ثبات أداة الاراسـة

تم حساب الثبات بطريقة الاتساق الداخلي وبحساب معامل كرونباخ ألفا (Cronbach Alpha)، وكما هو واضح في

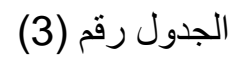

جدول (3): نتائج معامل كرونباخ ألفا(Cronbach Alpha ) لثبات أداة الدراسة

\begin{tabular}{|c|c|c|c|}
\hline قيمة ألفا & عدد الفقرات & عدد الحالات & 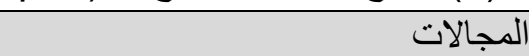 \\
\hline 0.84 & 12 & 54 & الحو افز وتأتثير ها على السلوك التنظيمي \\
\hline 0.86 & 15 & 54 & السلوك التنظيمي \\
\hline 0.88 & 27 & 54 & الدرجة الكلية \\
\hline
\end{tabular}

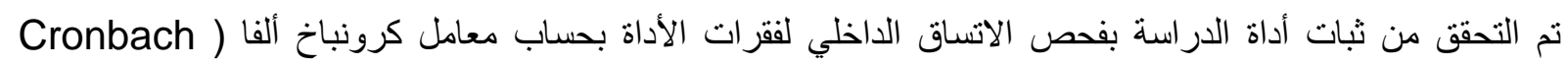
(Alpha

عرض النتائج ومناقثتها

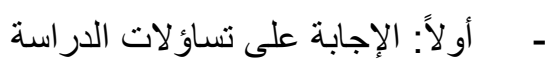

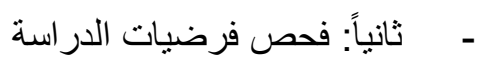
يتضمن هذا الفصل عرضاً كاملاً لأهم النتائج التي توصلت لها الدراسة، وذلك للإجابة عن تساؤلاتها، و التحقق من صحة فرضياتها، باستخدام التقنيات الإحصائية المناسبة. سؤال الأول: ما درجة التحفيز وأثره على السلوك التظظيمي؟

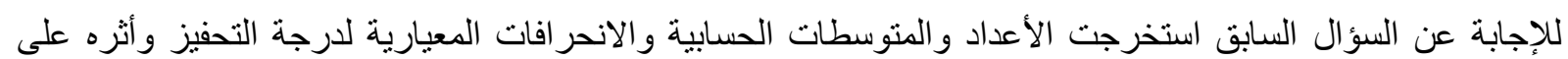

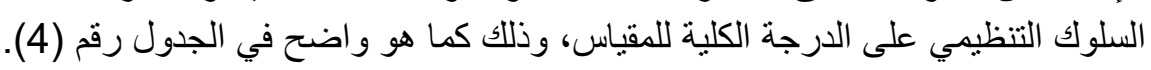

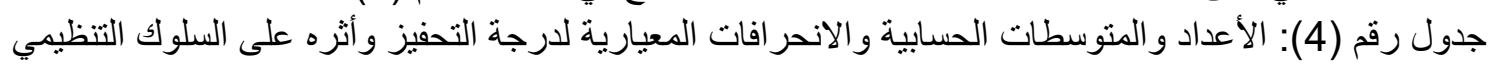

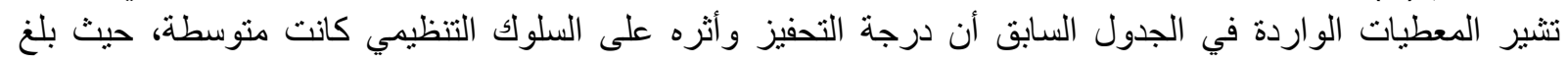
الدتوسط الحسابي لهذه الدرجة على الدرجة الكلية لمقياس الدراسة (3.26) ، مع انحر افت معياري (0.45).

\begin{tabular}{|c|c|c|c|}
\hline الانحر اف & المتوسط & & المتغير \\
\hline المعباري & الحسابي & ושה & \\
\hline 0.60 & 2.46 & 54 & الحو افز وتأثير ها على السلوك التنظيمي \\
\hline 0.49 & 3.89 & 54 & السلوك التنظيمي \\
\hline 0.45 & 3.26 & 54 & الدرجة الكلية \\
\hline
\end{tabular}

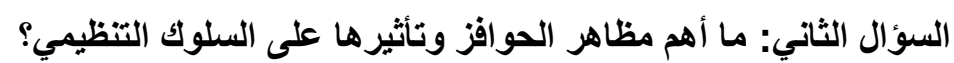

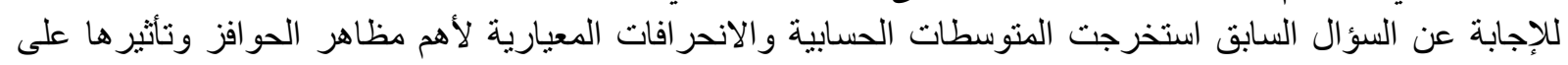

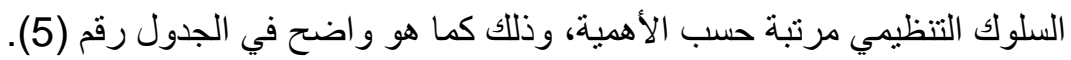
جدول رقم (5) المتوسطات الحسابية والانحر افات المعيارية لأهم مظاهر الحو افز وأنأثير ها على السلوك التنظيمي مرتبة حسب الأهمية (5 آلمن

\begin{tabular}{|c|c|c|c|c|}
\hline الدرجة & الالنياري & الحسني & المظاهر & الرقم \\
\hline كبيرة & .870 & 3.94 & أنقاضى بدل تنقل من و إلى المدرسة & b4 \\
\hline 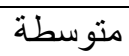 & .910 & 3.65 & تشركني المدرسة بدور ات تطويرية حسب الحاجة & b8 \\
\hline متوسطة & 1.16 & 2.65 & تثركني الادارة في اتخاذ القرارات الخاصة & b11 \\
\hline
\end{tabular}




\section{THE IMPACT OF MOTIVATION ON ORGANIZATIONAL BEHAVIOR}

\begin{tabular}{|c|c|c|c|c|}
\hline متوسطة & 1.28 & 2.50 & قامت المدرسة بتكريمي خلال السنة الدر اسية & b9 \\
\hline متوسطة & 1.07 & 2.46 & أتقاضى حو افز مالية بشكل دوري & b1 \\
\hline قليلة & 1.14 & 2.30 & هنالك جائزة سنوية للأداء الجيد تعلن عنها المدرسة & b12 \\
\hline قليلة & 1.11 & 2.24 & هناك مكافآت مالية سنوية للمعلمة ذات التقييم العالي & b2 \\
\hline قليلة & .890 & 2.20 & عادة ما أتعرض للتأنيب من قبل الإدارة & b6 \\
\hline قليلة & .950 & 2.19 & تم خفض أجري خلال السنة الأخيرة & b7 \\
\hline قليلة & .940 & 2.06 & استلمت كتاب شكر على أدائي خلال السنة الأخيرة & b10 \\
\hline قليلة & .650 & 1.72 & أتقاضى بدل وجبات غذائية من المدرسة & b5 \\
\hline قليلة & .760 & 1.70 & أنقاضى بدل سكن من المدرسة & b3 \\
\hline متوسطة & 0.60 & 2.46 & الدرجة الكلية & \\
\hline
\end{tabular}

تشير المعطيات الواردة في الجدول السابق أن درجة الحوافز ونأثير ها على السلوك التنظيمي كانت منوسطة حيث بلغ

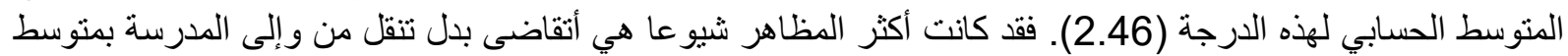

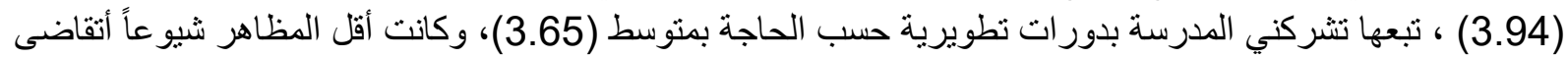

بدل سكن من المدرسة بمتوسط (1.70)

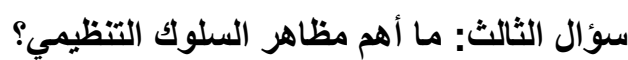
للإجابة عن السؤال السابق استخرجت المتوسطات الحسابية والانحر افات المعيارية لأهم مظاهر السلوك التنظيمي مرتبة

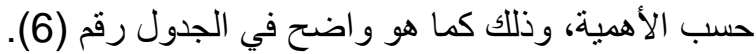
جدول رقم (6) المنوسطات الحسابية والانحر افات المعيارية لألهم مظاهر السلوك التنظيمي مرتبة حسب الأهمية

\begin{tabular}{|c|c|c|c|c|}
\hline الدرجة & 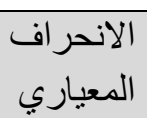 & 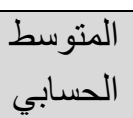 & المظاهر & 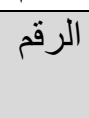 \\
\hline كبيرة & 0.70 & 4.33 & تحتل المدرسة نتائج متقدمة على الصعيد الأكاديمي & c3 \\
\hline كبيرة & 0.66 & 4.22 & أتقدم بأدائي كمدرسة خلال السنة الحالية & c6 \\
\hline كبيرة & 0.73 & 4.20 & لابي رغبة أكبر في الانجاز و التطوير & c7 \\
\hline كبيرة & 0.66 & 4.11 & أشعر بالتقدير و الاحتر ام من جميع العاملين في مؤسستي & c14 \\
\hline كبيرة & 1.06 & 4.07 & لا أرغب بالانتقال من هذه المدرسة & c5 \\
\hline كبيرة & 0.86 & 4.04 & أمتلك روح معنوية عالية & c4 \\
\hline 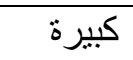 & 0.75 & 3.96 & لاي طاقة متجددة للعمل في المدرسة & c10 \\
\hline كبيرة & 0.82 & 3.96 & أشتر بالسعادة ورضا أنثاء تأدية عملي & c13 \\
\hline كبيرة & 0.95 & 3.91 & لا اشعر برغبة في التغيب عن الدوام & c8 \\
\hline كبيرة & 0.76 & 3.89 & أحسن الأداء الوظيفي للمدرسة خلال السنة الأخيرة & c2 \\
\hline 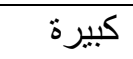 & 0.73 & 3.85 & أشعر بالأمان الوظيفي & c11 \\
\hline كبيرة & 0.87 & 3.74 & أحقق كافة أهدافي الوظيفية خلال السنة & c9 \\
\hline كبيرة & 1.00 & 3.70 & أتنافس على الأداء الجيد بين المدرسات & c1 \\
\hline متوسطة & 0.91 & 3.33 & أشعر بأن المدرسة تلبي العديد من رغباتي & c15 \\
\hline متوسطة & 0.99 & 3.15 & أنشعر بأن فرص النمو الوظيفي غير واضحة في & c12 \\
\hline كبيرة & 0.49 & 3.89 & الدرجة الكلية & \\
\hline
\end{tabular}

تشير المعطيات الواردة في الجدول السابق أن درجة السلوك التنظيمي كانت كبيرة حيث بلغ المتوسط الحسابي لهذه

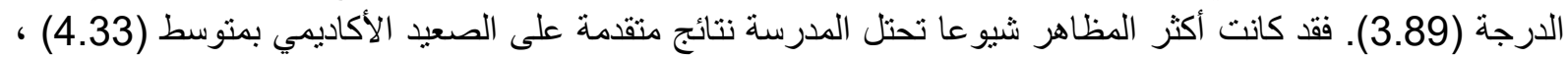

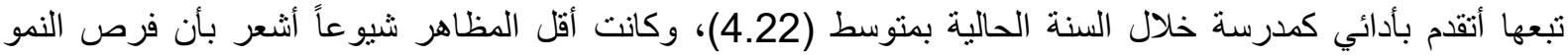
الوظيفي غير واضحة في المؤسسة بمتوسط (3.15) 
لا توجد فروق ذات دلالة إحصائية عند المستوى (a d 0.05) في درجة التحفيز وأثره على السلوك التنظيمي تعزى للتحقق من صحة الفرضية السابقة استخدم اختبار ت (t-test) للفروق في درجة التحفيز وأثره على السلوك التنظيمي تعزى لمتغير الجنس، وذلك كما هو واضح في الجدول رقم (7).

\begin{tabular}{|c|c|c|c|c|c|c|c|}
\hline الإلالائية & قالمحسوبة & الحرجية & الالحمر اف & الحسابي & العدد & الجنس & المجالات \\
\hline \multirow[b]{2}{*}{5190} & \multirow[b]{2}{*}{.6500- } & \multirow[b]{2}{*}{52} & 0.53 & 2.41 & 27 & ذكر & \multirow{2}{*}{ التنظي الحو السلوك } \\
\hline & & & 0.68 & 2.52 & 27 & أنتى & \\
\hline \multirow{2}{*}{.9140} & \multirow{2}{*}{0.108} & & 0.54 & 3.90 & 27 & ذكر & \multirow{2}{*}{ السلوك التنظيمي } \\
\hline & & & 0.45 & 3.89 & 27 & أنثى & \\
\hline \multirow{2}{*}{.7500} & \multirow{2}{*}{.3210- } & \multirow{2}{*}{52} & 0.41 & 3.24 & 27 & ذكر & \multirow{2}{*}{ الدرجة الكلية } \\
\hline & & & 0.49 & 3.28 & 27 & أنثى & \\
\hline
\end{tabular}

جدول رقم (7): نتائج اختبار ت (t-test) للفروق في درجة التحفيز وأثره على السلوك التنظيمي تعزى لمتغير الجنس

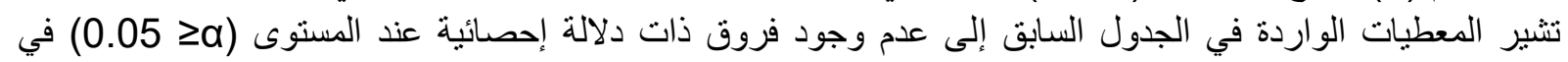

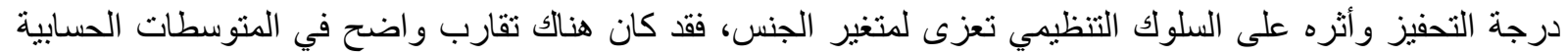
و على اختلاف الجنس، وذلك كما هو واضح من الجدول السابق.

الفرضية الثانية

لا توجد فروق ذات دلالة إحصائية عند المستوى (a

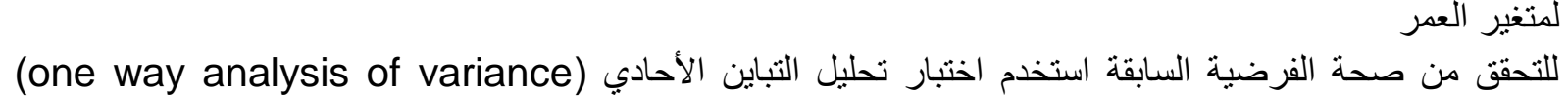

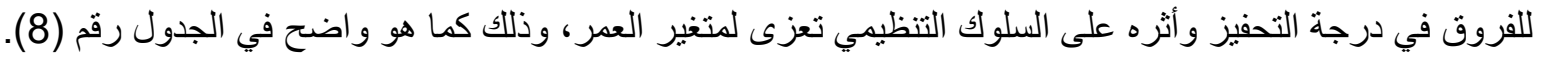

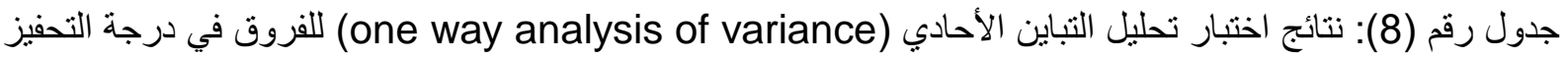

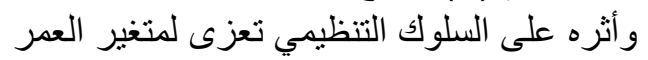

\begin{tabular}{|c|c|c|c|c|c|c|}
\hline الالدحصائية & قالمسمة فة & متوسط & الدرجة & مجموع & مصدر & المجالات \\
\hline \multirow{4}{*}{0.017} & \multirow{4}{*}{4.428} & 1117 & 0 & 2001 & It o II. & \multirow{4}{*}{ واتلثير هانيا } \\
\hline & & & & & & \\
\hline & & 0.327 & 49 & 16.016 & داخل المجموعات & \\
\hline & & & 51 & 18.910 & المجموع & \\
\hline \multirow{3}{*}{0.069} & \multirow{3}{*}{2.818} & 0.573 & 2 & 1.145 & بين المجمو عات & \multirow{3}{*}{ التنظيمي } \\
\hline & & 0.203 & 49 & 9.957 & داخل المجمو عات & \\
\hline & & & 51 & 11.102 & المجموع & \\
\hline \multirow{3}{*}{0.005} & \multirow{3}{*}{5.805} & 0.912 & 2 & 1.824 & بين المجمو عات & \multirow{3}{*}{ الدرجة الكلية } \\
\hline & & 0.157 & 49 & 7.700 & داخل المجمو عات & \\
\hline & & & 51 & 9.524 & المجموع & \\
\hline
\end{tabular}




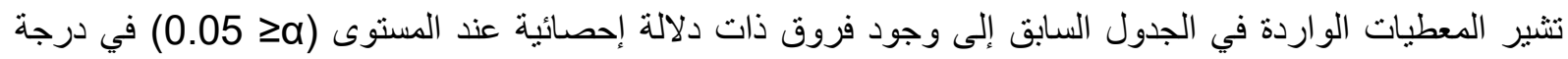

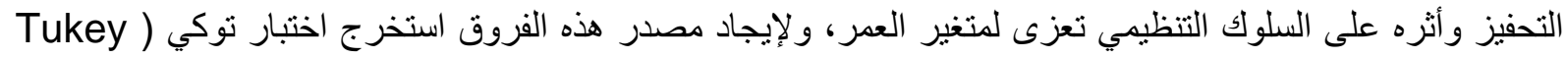

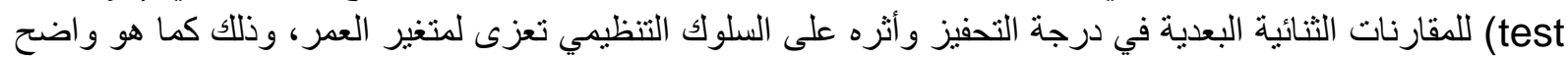

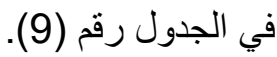
جدول رقم (9) نتائج اختبار نوكي(Tukey test) للمقارنات الثنائية البعدية في درجة التحفيز و أثره على السلوك التنظيمي تعزى لمتغير العمر (9تر

\begin{tabular}{|c|c|c|c|c|}
\hline 45 فاكثر & 30 - أقل من 45 & 30 سنة فاقل & العمر & المجالات \\
\hline${ }^{*} 0.65135$ & -0.55501 & & 30 سنة فاقل & \multirow{3}{*}{ 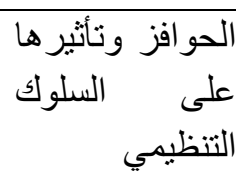 } \\
\hline-0.09634 & & & 30 - أقل من 45 & \\
\hline & & & 45 فاكثر & \\
\hline-0.40855 & -0.35425 & & 30 سنة فاقل & \multirow{3}{*}{ السلوك التنظيمي } \\
\hline-0.05430 & & & 30 - أقل من 45 & \\
\hline & & & 45 فاكثر & \\
\hline${ }^{*} 0.51646$ & ${ }^{*} 0.44348$ & & 30 سنة فاقل & \multirow{3}{*}{ الدرجة الكلية } \\
\hline-0.07298 & & & 30 - أقل من 45 & \\
\hline & & & 45 فاكثر & \\
\hline
\end{tabular}

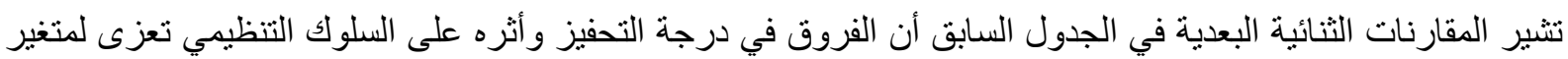

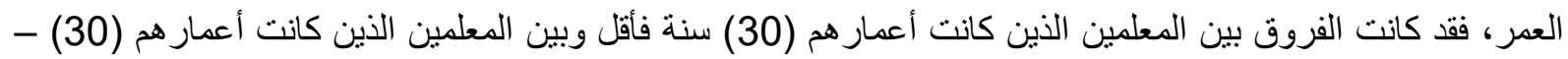

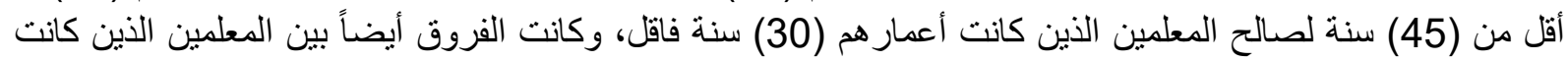

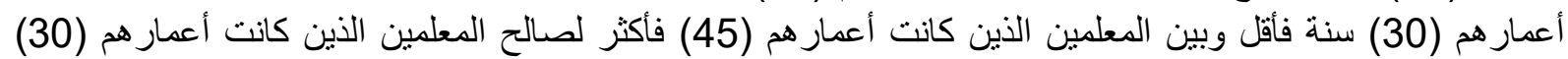

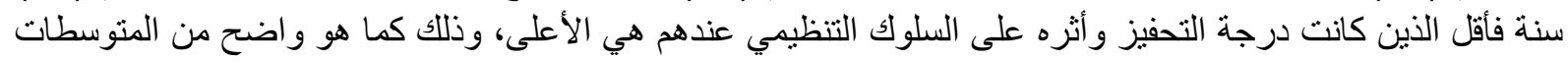

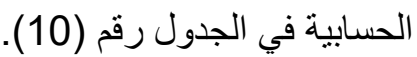
جدول رقم (10) الأعداد و المتوسطات الحسابية والانحر افات المعيارية لدرجة التحفيز و أثره على السلوك التنظيمي تعزى لمتغير العمر

\begin{tabular}{|c|c|c|c|c|}
\hline الانحر اف المعياري & المتوسط الحسابي & العدد ال العد & العمر & المجالات \\
\hline .750 & 2.98 & 9 & 30 سنة فاقل & \multirow{3}{*}{ السو افز وتأثنير ها على التنظيمي } \\
\hline .370 & 2.42 & 17 & 30 - أقل من 45 & \\
\hline .600 & 2.33 & 26 & 45 فاكثر & \\
\hline .490 & 4.24 & 9 & 30 سنة فاقل & \multirow{3}{*}{ السلوك التنظيمي } \\
\hline .430 & 3.89 & 17 & 30 - أقل من 45 & \\
\hline .440 & 3.83 & 26 & 45 فاكثر & \\
\hline .430 & 3.68 & 9 & 30 سنة فاقل & \multirow{3}{*}{ الدرجة الكلية } \\
\hline .310 & 3.23 & 17 & 30 - أقل من 45 & \\
\hline .420 & 3.16 & 26 & 45 فاكثر & \\
\hline
\end{tabular}

الفرضية الثالثة

لا توجد فروق ذات دلالة إحصائية عند المستوى (a) 0.05) في درجة التحفيز وأثره على السلوك التنظيمي تعزى لمتغير المؤهل العلمي في ذون 
للتحقق من صحة الفرضية السابقة استخدم اختبار تحليل التباين الأحادي (one way analysis of variance) للفروق في درجة التحفيز و أثره على السلوك التنظيمي تعزى لمتغير المؤهل العلمي، وذللك كما هو و اضح في الجدول رائل رقم

جدول رقم (11): نتائج اختبار تحليل التباين الأحادي (one way analysis of variance) للفروق في درجة

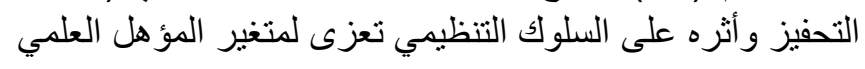

\begin{tabular}{|c|c|c|c|c|c|c|}
\hline الإلالالة & قالمسمة فبة & متوسط & الحرية & المربعات & مصدر & المجالات \\
\hline \multirow{3}{*}{.9740} & \multirow{3}{*}{.0260} & .0100 & 2 & .0200 & بين المجمو عات & \multirow{3}{*}{ 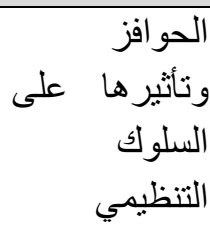 } \\
\hline & & .3800 & 50 & 19.017 & داخل المجمو عات & \\
\hline & & & 52 & 19.037 & المجموع & \\
\hline \multirow{3}{*}{.0310} & \multirow{3}{*}{3.727} & .7210 & 2 & 1.441 & بين المجمو عات & \multirow{3}{*}{ لنتظيمي } \\
\hline & & .1930 & 50 & 9.667 & داخل المجمو عات & \\
\hline & & & 52 & 11.108 & المجموع & \\
\hline \multirow{3}{*}{.2550} & \multirow{3}{*}{1.406} & .2550 & 2 & .5090 & بين المجمو عات & \multirow{3}{*}{ الدرجة الكلية } \\
\hline & & .1810 & 50 & 9.055 & داخل المجمو عات & \\
\hline & & & 52 & 9.564 & المجموع & \\
\hline
\end{tabular}

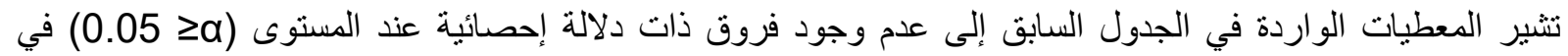

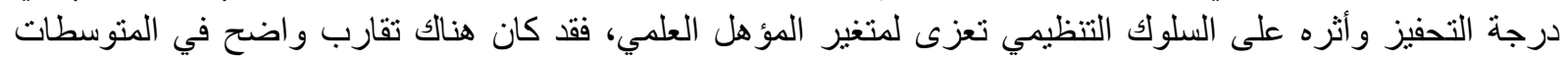

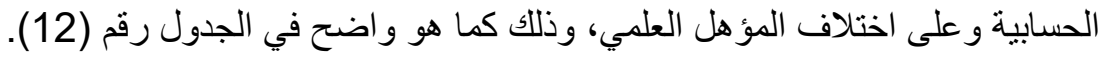

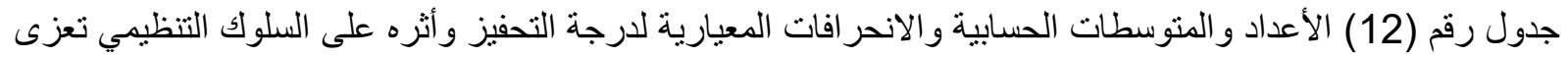

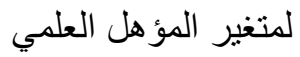

\begin{tabular}{|c|c|c|c|c|}
\hline الانحر اف المعياري & المتوسط الحسابي & العدد العد & المؤهل العلمي & المجالات \\
\hline .600 & 2.49 & 30 & بكالوريوس & \multirow{3}{*}{ السلوك التنظيمي وتأثنير ها على } \\
\hline .630 & 2.46 & 22 & ماجستير & \\
\hline & 2.41 & 1 & دكتور اه & \\
\hline .420 & 3.99 & 30 & بكالوريوس & \multirow{3}{*}{ السلوك التنظيمي } \\
\hline .450 & 3.88 & 22 & ماجستير & \\
\hline & 2.80 & 1 & دكتور اه & \\
\hline .380 & 3.32 & 30 & بكالوريوس & \multirow{3}{*}{ الدرجة الكلية } \\
\hline .470 & 3.25 & 22 & ماجستير & \\
\hline . & 2.62 & 1 & دكتور اه & \\
\hline
\end{tabular}

الفرضية الرابعة

لا نوجد فروق ذات دلالة إحصائية عند المستوى (a) 0.05) في درجة التحفيز وأثره على السلوك التنظيمي تعزى لمتغير سنوات الخبرة للتحقق من صحة الفرضية السابقة استخدم اختبار تحليل التباين الأحادي (one way analysis of variance)

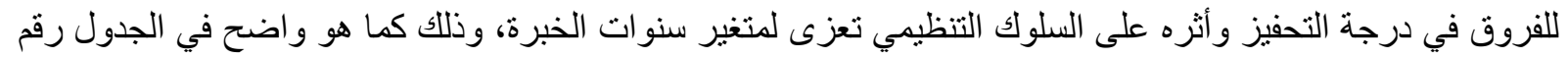
للفروق في درجة التحفيز 13) و أثره على السلوك التنظيمي تعزى لمتغير سنوات الخبرة 


\begin{tabular}{|c|c|c|c|c|c|c|}
\hline الإحصائية & الديموبة ف & المربعات & درجات & المربعات & مصدر & المجالات \\
\hline \multirow{3}{*}{0.005} & \multirow{3}{*}{5.965} & 1.851 & 2 & 3.703 & بين المجمو عات & \multirow{3}{*}{ 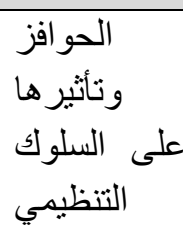 } \\
\hline & & 0.310 & 49 & 15.208 & داخل المجمو عات & \\
\hline & & & 51 & 18.910 & الدجموع & \\
\hline \multirow{3}{*}{0.078} & \multirow{3}{*}{2.684} & 0.548 & 2 & 1.096 & بين المجمو عات & \multirow{3}{*}{ التنظيمي } \\
\hline & & 0.204 & 49 & 10.006 & داخل المجمو عات & \\
\hline & & & 51 & 11.102 & الدجموع & \\
\hline \multirow{3}{*}{0.003} & \multirow{3}{*}{6.764} & 1.030 & 2 & 2.061 & بين المجمو عات & \multirow{3}{*}{ الدرجة الكلية } \\
\hline & & 0.152 & 49 & 7.463 & داخل المجمو عات & \\
\hline & & & 51 & 9.524 & المجموع & \\
\hline
\end{tabular}

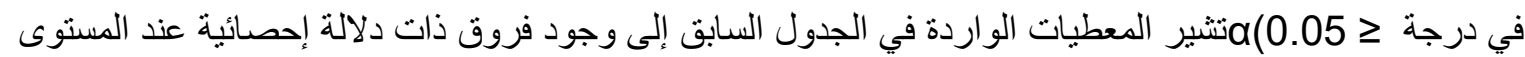

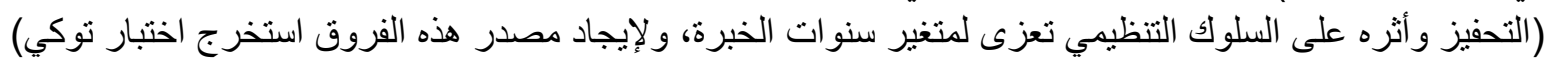

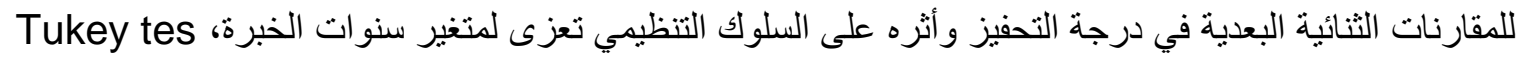

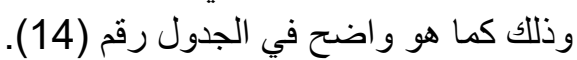
للمقارنات الثنائية البعدية في درجة التحفيز و أثره على السلوك Tukey test جدول رقم (14): نتائج اختبار نوكي(

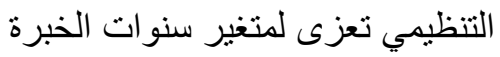
تشير المقارنات الثنائية البعدية في الجدول السابق أن الفروق في درجة التحفيز وأثره على السلوك التنظيمي تعزى لمتغير

\begin{tabular}{|c|c|c|c|}
\hline 10 فأعلى & 5 إلى أقل من 10 سنو ات & أقل من 5 سنو ات & سنوات الخبرة \\
\hline $.39881-0$ & .402780 & & أقل من 5 سنو ات \\
\hline $.80159^{\star} 0$ & & & 5 إلى أقل من 10 سنو ات \\
\hline & & & 10 فأعلى \\
\hline $.26111-0$ & .161110 & & أقل من 5 سنو ات \\
\hline $.42222-0$ & & & 5 إلى أقل من 10 سنو ات \\
\hline & & & 10 فأعلى \\
\hline $.32231-0$ & .268520 & & أقل من 5 سنوات \\
\hline $.59083^{*} 0$ & & & 5 إلى أقل من 10 سنو ات \\
\hline & & & 10 10 فأعلى \\
\hline
\end{tabular}

سنوات الخبرة، فقد كانت الفروق بين المعلمين الذين كانت سنوات الخبرة لديهح (5) إلى أقل من (10) سنوات التبرة وبين

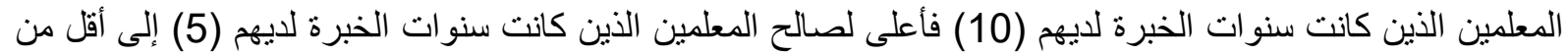

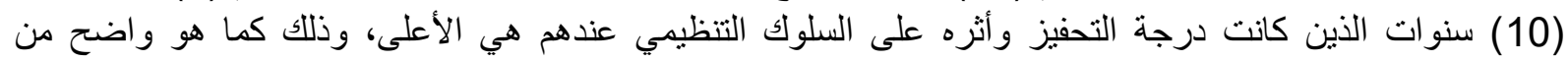
المتوسطات الحسابية في الجدول رقم (15) (15) التون جدول رقم (15): الأعداد و المتوسطات الحسابية والانحر افات المعيارية لدرجة التحفيز و أثره على السلوك التنظيمي تعزى لمتغير سنو ات الخبرة

\begin{tabular}{|c|c|c|c|c|}
\hline الانحر اف المعياري & المتوسط الحسابي & العدد & سنوات الخبرة & المجالات \\
\hline .570 & 2.75 & 4 & أقل من 5 سنوات & الحو افز وتأثثير ها على \\
\hline .870 & 3.15 & 6 & 5 إلى أقل من 10 سنوات & السلوك التنظيمي \\
\hline
\end{tabular}




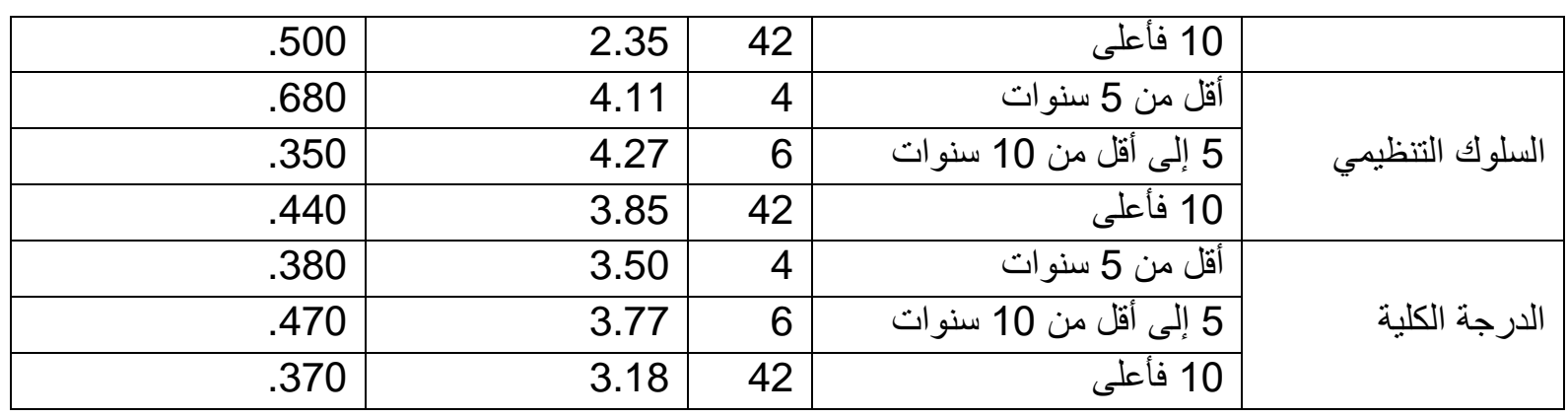

جدول رقم (16).

\begin{tabular}{|c|c|c|}
\hline النسبة المئوية & العدد & المتغير ات \\
\hline & & ما أهم الحو افز التي تنتقدها/ ينها وترى/ين أنك بحاجة لها؟ \\
\hline 54.1 & 20 & الحوافز المعنوية \\
\hline 8.1 & 3 & الحوافز المادية \\
\hline 8.1 & 3 & والتريام برحلات ترفيهية بشكل دوري كسر الروتين وكنوع من التغيير \\
\hline 2.7 & 1 & 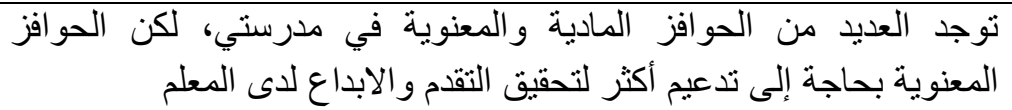 \\
\hline 2.7 & 1 & لايوجد \\
\hline 2.7 & 1 & 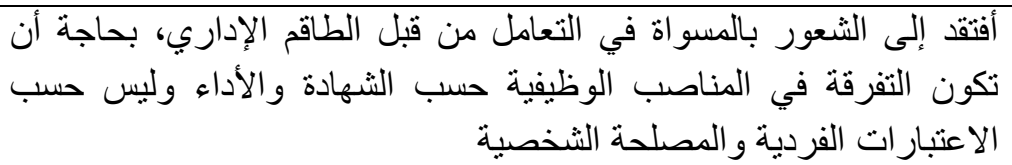 \\
\hline 2.7 & 1 & الأمن الوظيفي من ناحية رخصة التعليم التيمي \\
\hline 2.7 & 1 & 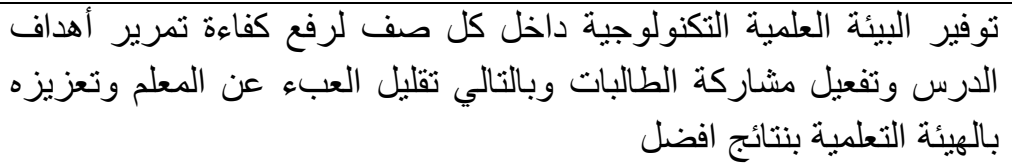 \\
\hline 2.7 & 1 & 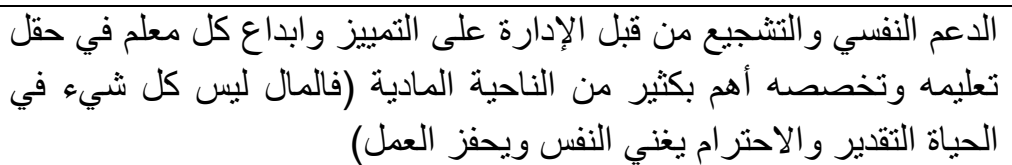 \\
\hline 2.7 & 1 & 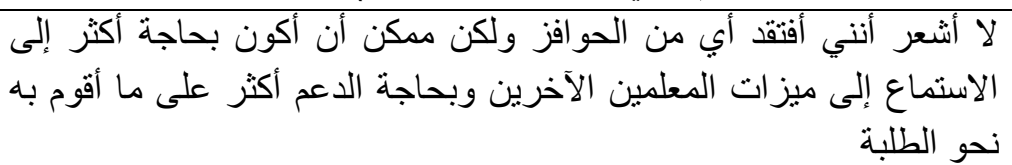 \\
\hline 2.7 & 1 & الحو افز السنوية \\
\hline 2.7 & 1 & 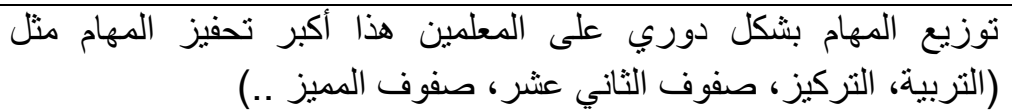 \\
\hline 2.7 & 1 & من أهم الحوافز التطور في الهرم الوظيفي كأن أعلم صفوف اعلى ـ \\
\hline 2.7 & 1 & 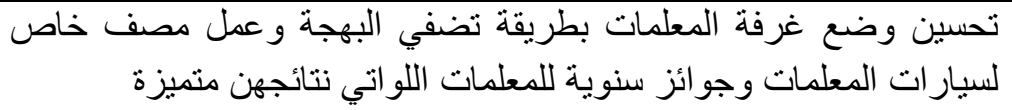 \\
\hline
\end{tabular}

\section{مناقثنة النتائج المتعقة بأسئلة الاراسة}

مناقثة النتائج المتطقة بالسؤال الأول: "ما درجة التحفيز وأثره على السلوك التنظيمي؟" لقد أظهرت النتائج المشار إليها في الجدول (4) أن درجة التحفيز وأثره على السلوك التنظيمي قد أتت بدرجة متوسطة

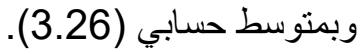


وتعزى ذلك إلى أن التحفيز يؤثر على السلوك التنظيمي باختلاف درجته، كل مؤسسة أو منظمة تختلف درجة التحفيز فيها

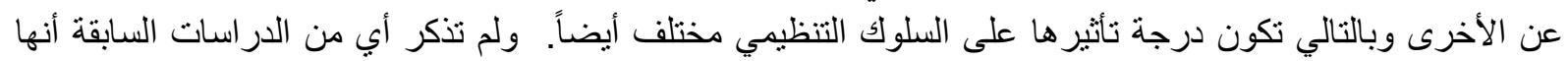

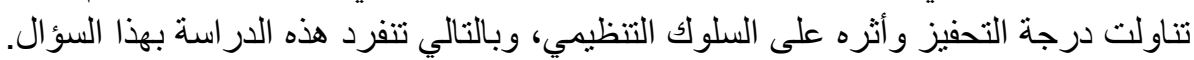

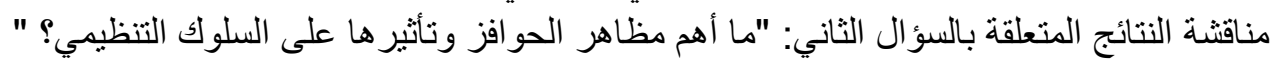

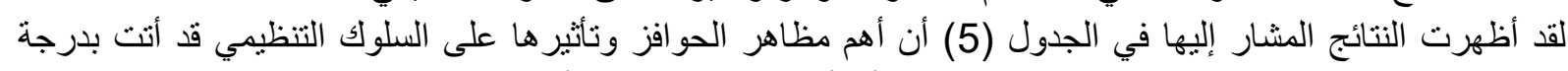

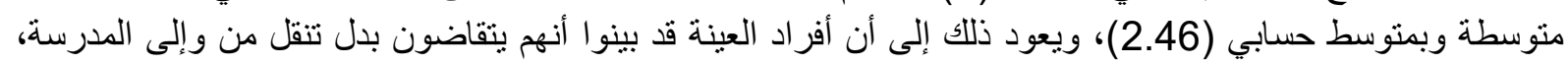

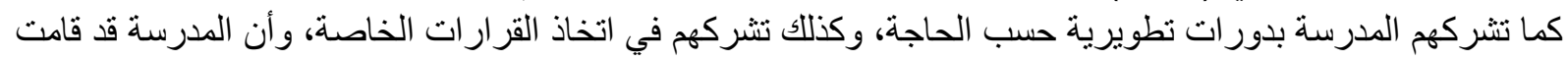

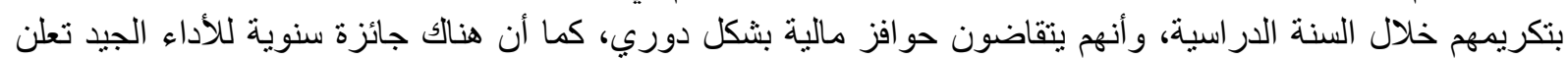

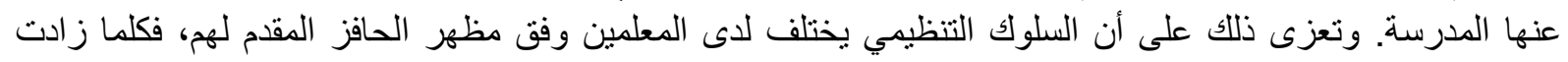

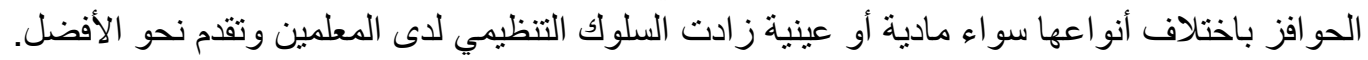

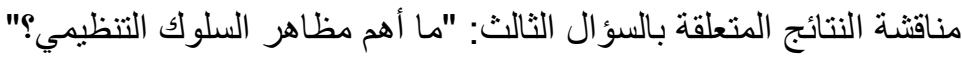

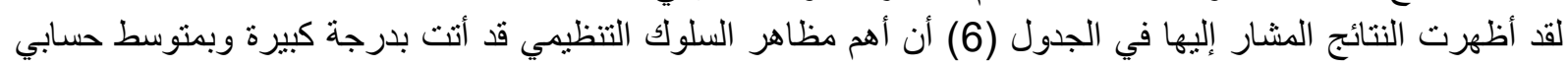

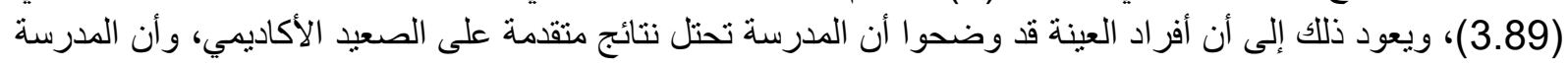

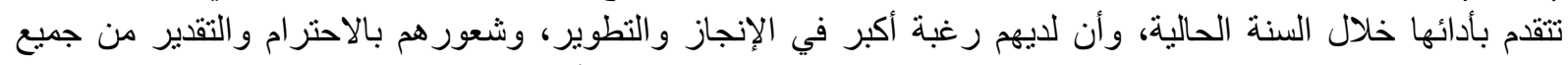

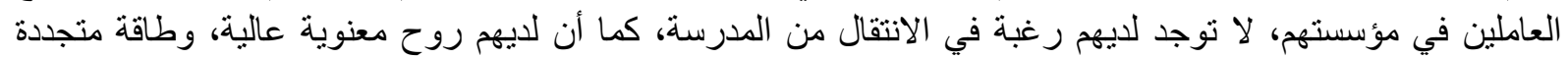

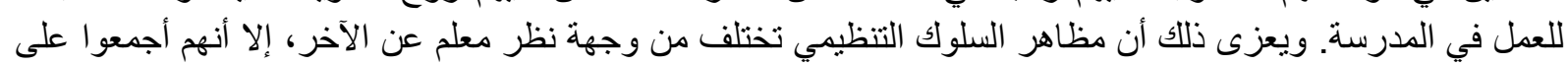
أن للمدرسة دور كبير في تحديد مظاهر السلوك التنظيمي السائد فيها.

\section{مناقشة فرضيات الاراسة:

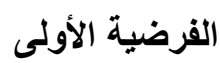

"لا توجد فروق ذات دلالة إحصائية عند المسنوى (a) (0.05) في درجة التحفيز وأثره على السلوك التنظيمي تعزى

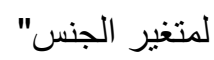
للتحقق من صحة الفرضية الأولى استخدم اختبار ت (t-test) لقياس دلالة الفروق في المتوسطات الحسابية للدرجة الكلية

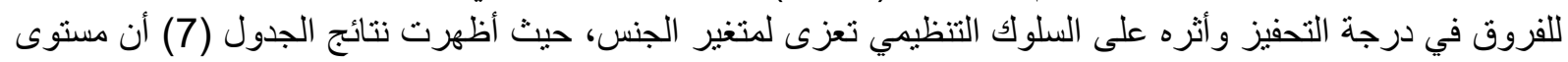

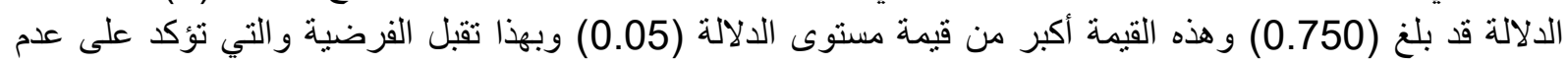

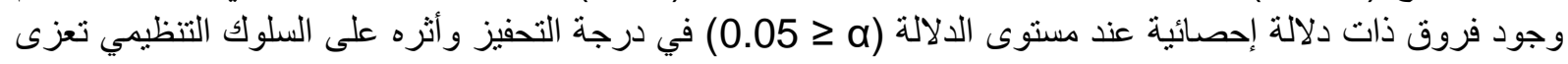

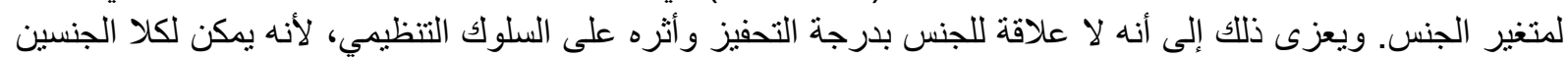

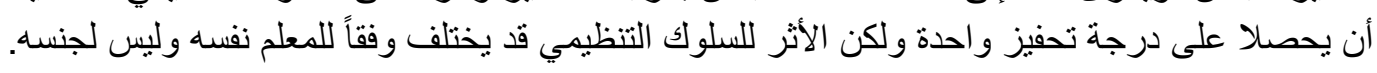

الفرضية الثانية

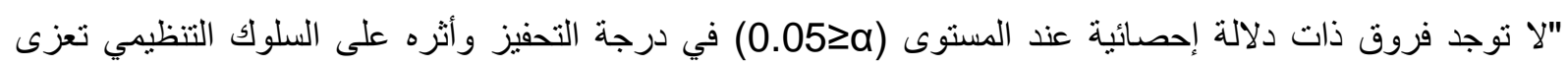

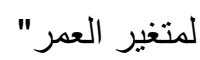
للتحقق من صحة الفرضية الثانية استخدم اختبار ت (t-test) لقياس دلالة الفروق في المتوسطات الحسابية للدرجة الكلية

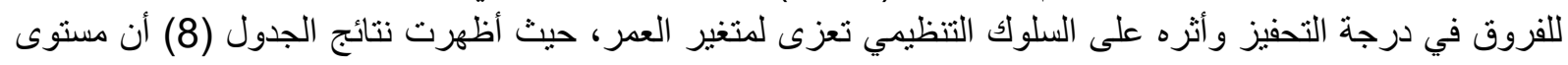

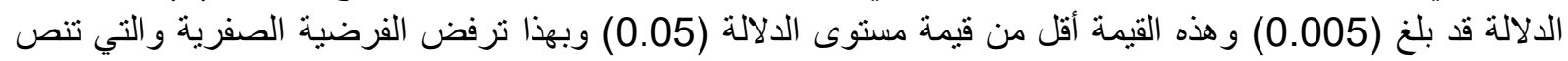

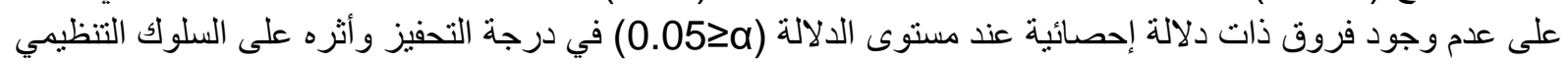

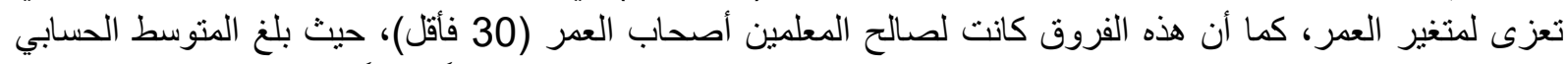

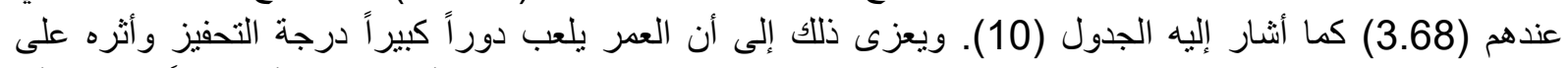

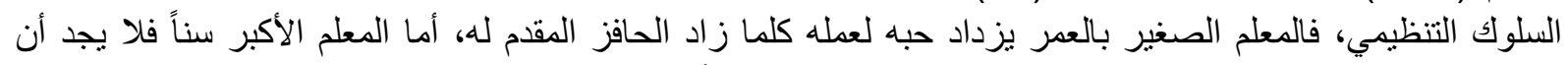
للحو افز نأثير على سلوكه، و وعله بالمقارنة مع المعلمين الأصغر سناً. الفرضية الثالثة

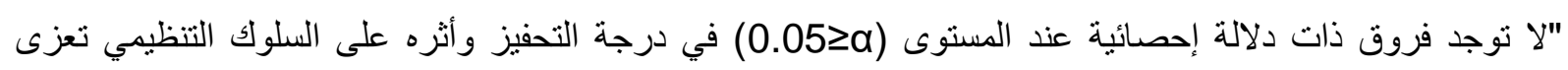

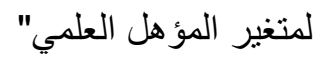


للتحقق من صحة الفرضية الثالثة استخدم اختبار تحليل التباين الأحادي لقياس دلالة الفروق في المتوسطات الحسابية

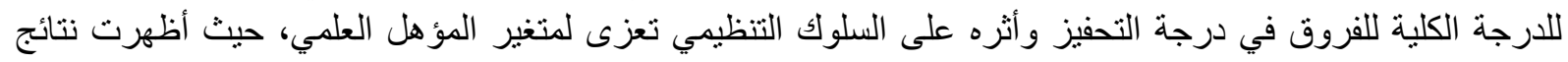

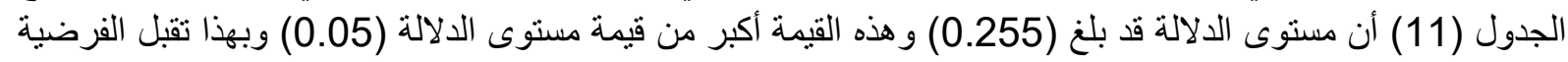

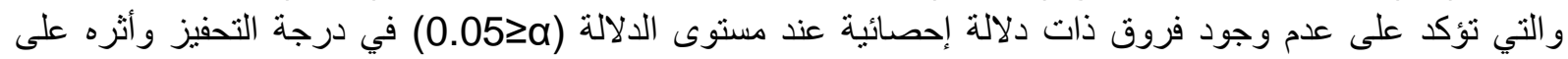

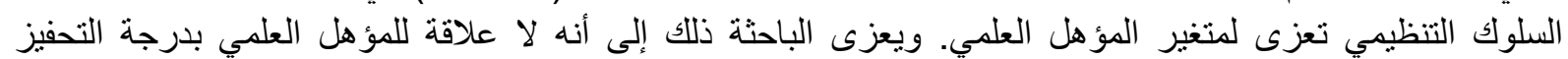

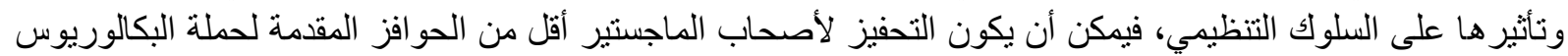

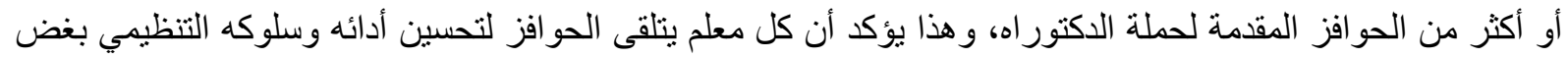

النظر عن مؤهله العلهي.

الفرضية الرابعة

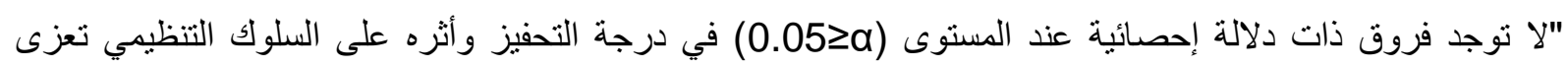

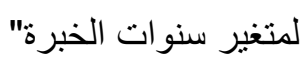

للتحقق من صحة الفرضية الر ابعة استخدم اختبار تحليل التباين الأحادي لقياس دلالة الفروق في المتوسطات الحسابية

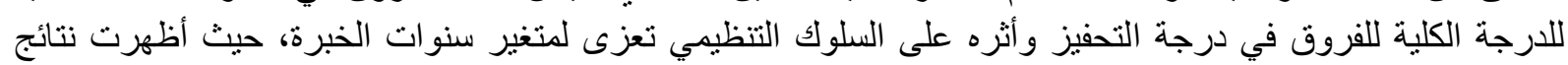

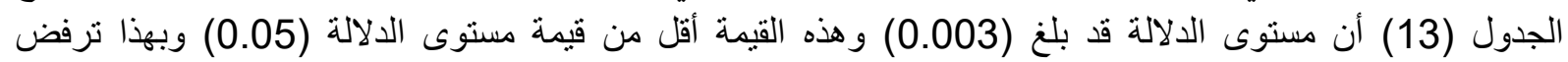

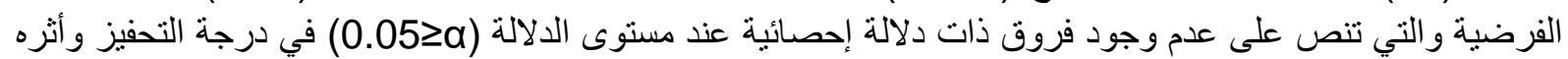

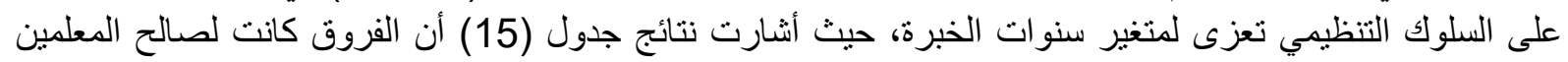

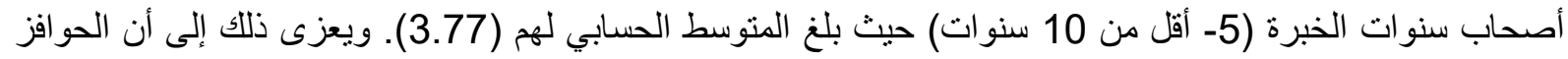

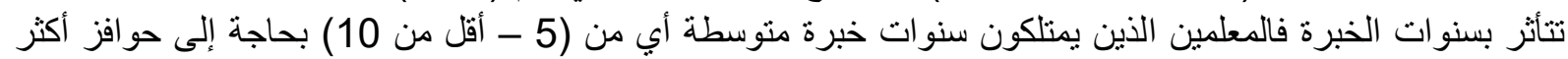

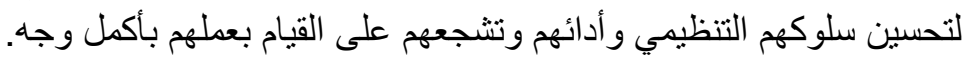

ملخص النتائج والاستتتاجات والتوصيات

النتائج

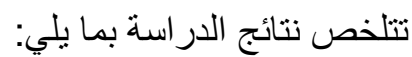

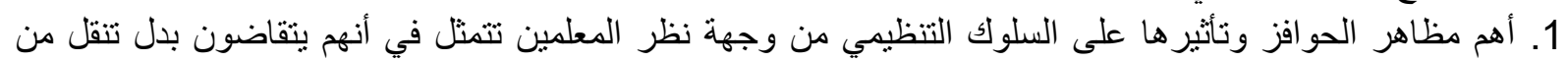

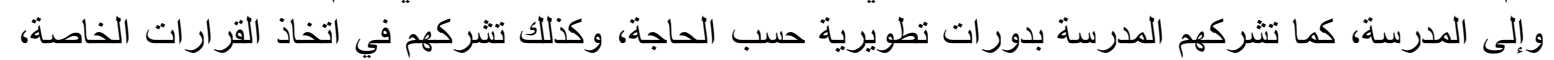

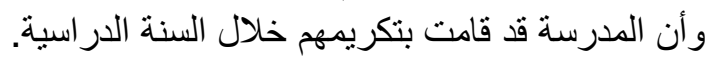

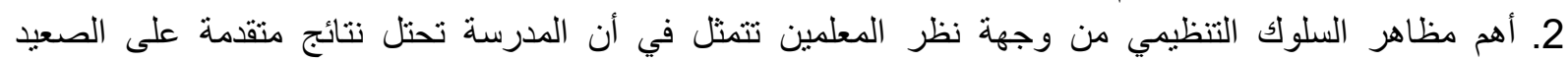

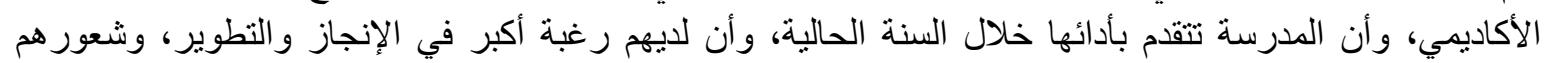

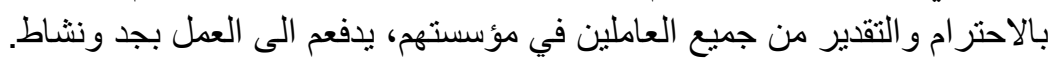

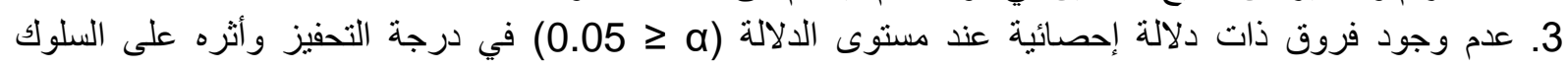
التظظيمي تعزى لمتغير الجنس

4. عدم وجود فروق ذات دلالة إحصائية عند مستوى الدلالة (a > 0.05) في درجة التحفيز و أثره على السلوك التنظيمي تعزى لمتغير المؤهل العلمي.

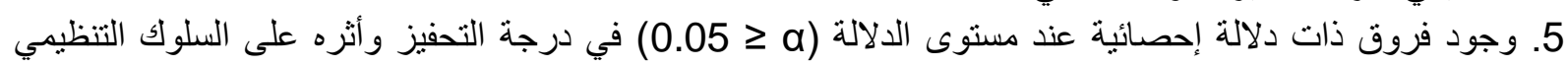

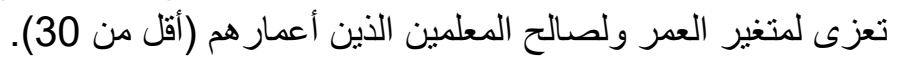

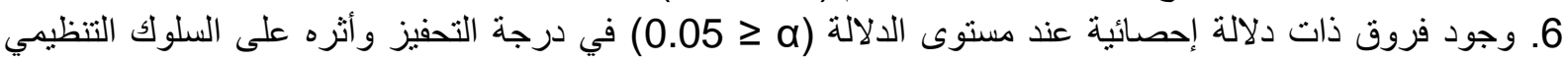

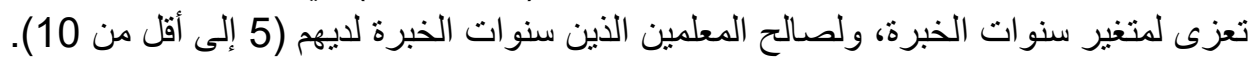

التوصيات

في ضوء النتائج التي توصلت إليها هذه الدراسة نوصي بما يأتي:

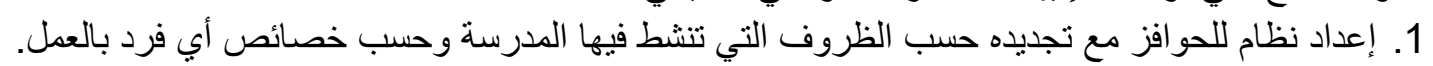
2. البعد عن العلاقة الثخصية في منح الحو افز. 


$$
\text { 3. توفير العدالة في توزيع الحوافز. }
$$

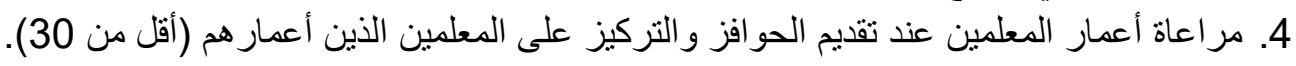

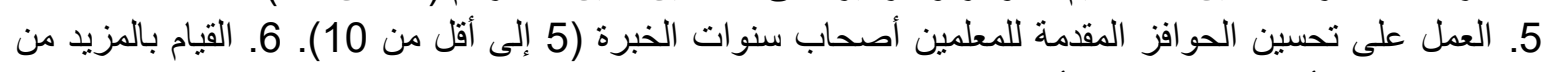
الدراسات والأبحاث حول كيفية تأثير الحوافز على السين السلوك التنظيمي.

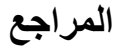 \\ المراجع العربية}

أحدد، ماهر. (2005). التنظيم، الدليل العلمي و الهياكل و الدمارسات التتظيمية، الدار الجامعية، مصر

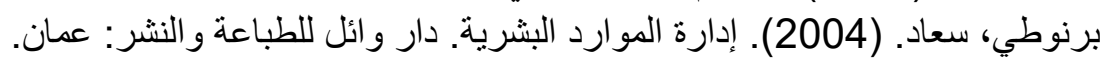

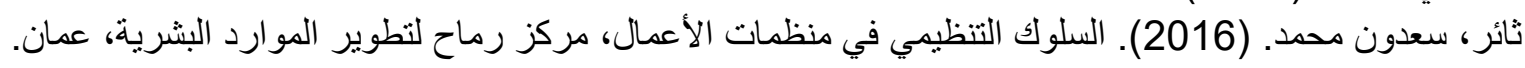
الجهاز المركزي للإحصاء الفلسطيني. (2011).

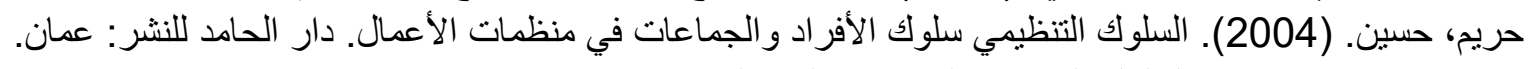

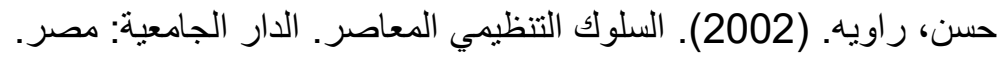

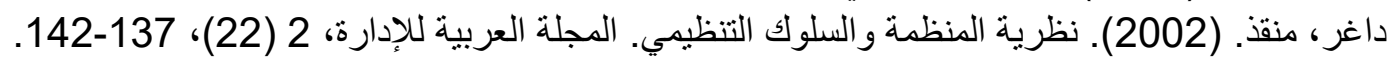

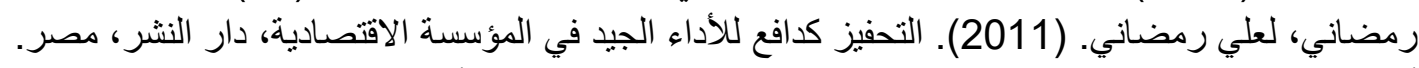
أبو الزيت، بلال. (2010). الحو افز والرضى الوضئ الوظيفي، هدي الإسلام، الأردن.

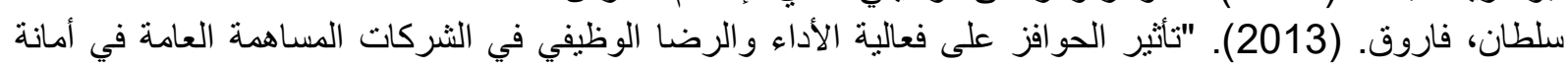

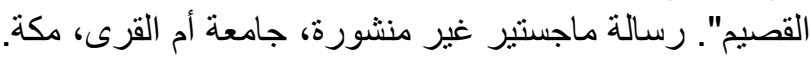

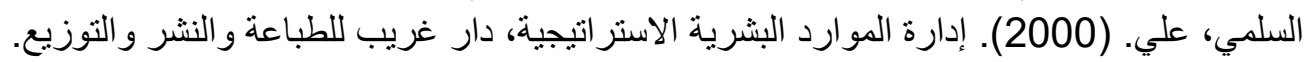

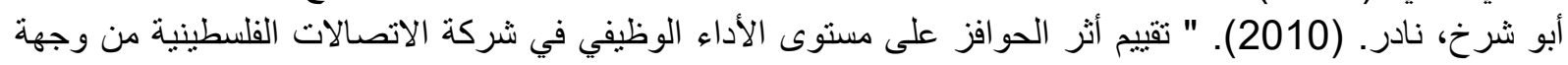

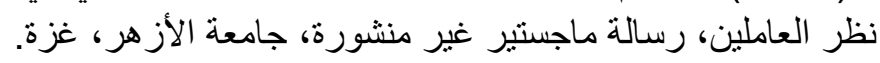

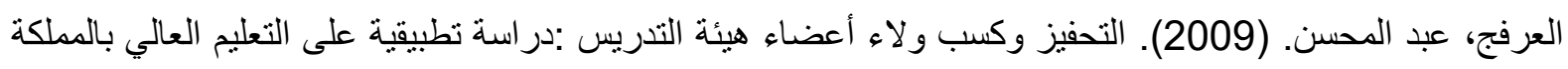

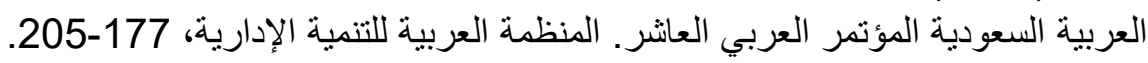

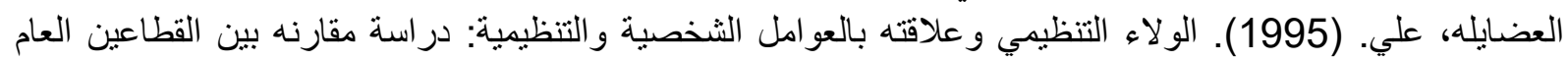

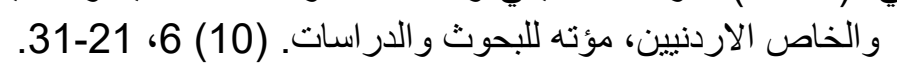

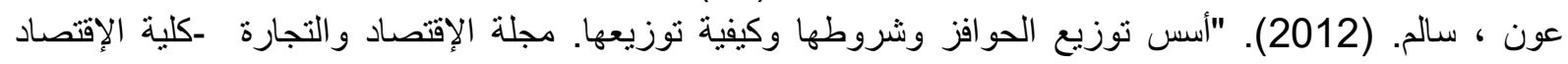

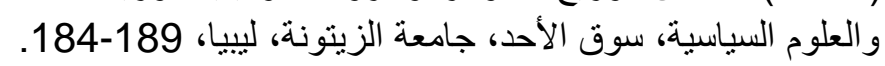

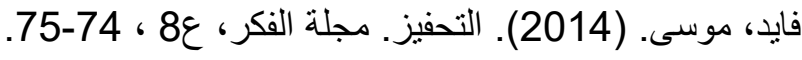

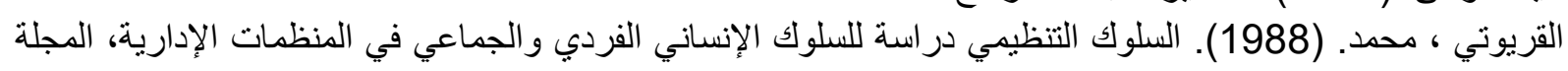

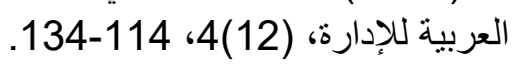

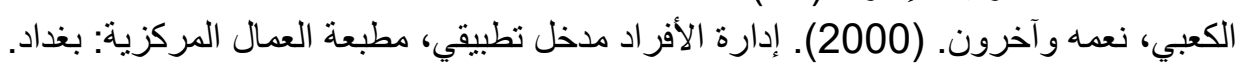

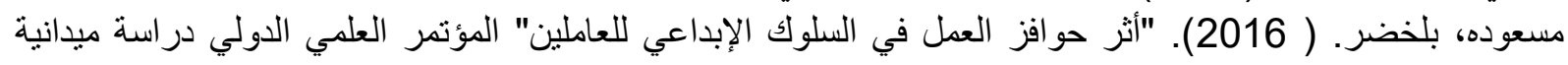

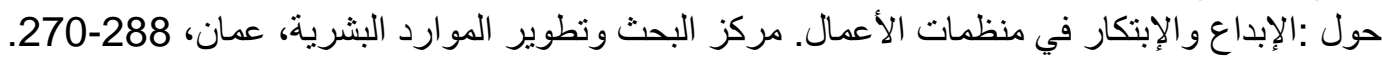

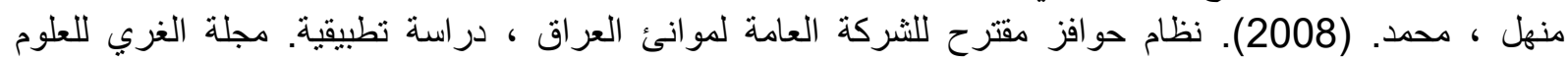

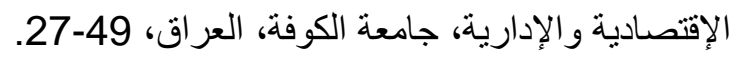

المؤمن، عدنان. (2018). أثر التحفيز على الرضا الوظية الوظيفي :دراسة على شركة زين للاتصالات الخلوية الكويتية". مجلة

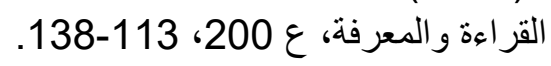

ميا، علي وآخرون. (2009). "أنثر الحوافز على أداء الموارد البشرية وولائها الوظيفي :دراسة تطبيقية على شركة

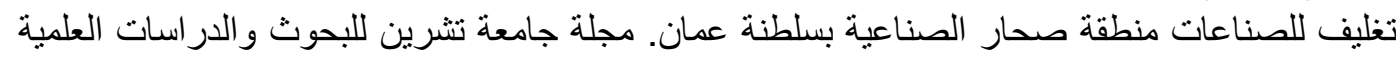
سلسلة العلوم الإقتصادية و القانونية، سوريا 45-29.

ياغي، محمد. (1986). " تقييم الموظف العام للحو افز في الأجهزة الحكومية الاردنية": دراسة ميدانية مقارنة. المنظمة

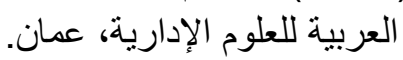


Kersten, E. (2)013, The Art of Demotivation, Despair, Inc, USA.

$$
\text { المواقع الإكترونية }
$$

https://www.arrajol.com/content/112776 